\title{
Health Benefits and Applications of Goji Berries in Functional Food Products Development: A Review
}

\author{
Bojana B. Vidović ${ }^{1, *,+(\mathbb{D}}$, Danijel D. Milinčić ${ }^{2,+} \mathbb{D}$, Mirjana D. Marčetić ${ }^{3} \mathbb{D}$, Jelena D. Djuriš ${ }^{4}$, Tijana D. Ilić ${ }^{1}$, \\ Aleksandar Ž. Kostić ${ }^{2}$ and Mirjana B. Pešić ${ }^{2}$ D
}

1 Department of Bromatology, Faculty of Pharmacy, University of Belgrade, Vojvode Stepe 450, 11221 Belgrade, Serbia; tijana.ilic@pharmacy.bg.ac.rs

2 Department of Chemistry and Biochemistry, Faculty of Agriculture, University of Belgrade, Nemanjina 6, 11080 Belgrade, Serbia; danijel.milincic@agrif.bg.ac.rs (D.D.M.); akostic@agrif.bg.ac.rs (A.Ž.K.); mpesic@agrif.bg.ac.rs (M.B.P.)

3 Department of Pharmacognosy, Faculty of Pharmacy, University of Belgrade, Vojvode Stepe 450, 11221 Belgrade, Serbia; mirjana.marcetic@pharmacy.bg.ac.rs

4 Department of Pharmaceutical Technology and Cosmetology, Faculty of Pharmacy, University of Belgrade, Vojvode Stepe 450, 11221 Belgrade, Serbia; jelena.djuris@pharmacy.bg.ac.rs

* Correspondence: bojana.vidovic@pharmacy.bg.ac.rs

+ These authors contributed equally to this work.

check for updates

Citation: Vidović, B.B.; Milinčić, D.D.; Marčetić, M.D.; Djuriš, J.D.; Ilić, T.D.; Kostić, A.Ž.; Pešić, M.B. Health Benefits and Applications of Goji Berries in Functional Food Products Development: A Review. Antioxidants 2022, 11, 248. https:// doi.org/10.3390/antiox11020248

Academic Editors: Michał Swieca and Ireneusz Kapusta

Received: 4 January 2022

Accepted: 25 January 2022

Published: 27 January 2022

Publisher's Note: MDPI stays neutral with regard to jurisdictional claims in published maps and institutional affiliations.

Copyright: (c) 2022 by the authors. Licensee MDPI, Basel, Switzerland. This article is an open access article distributed under the terms and conditions of the Creative Commons Attribution (CC BY) license (https:// creativecommons.org/licenses/by/ $4.0 /)$.

\begin{abstract}
Goji berries have long been used for their nutritional value and medicinal purposes in Asian countries. In the last two decades, goji berries have become popular around the world and are consumed as a functional food due to wide-range bioactive compounds with health-promoting properties. In addition, they are gaining increased research attention as a source of functional ingredients with potential industrial applications. This review focuses on the antioxidant properties of goji berries, scientific evidence on their health effects based on human interventional studies, safety concerns, goji berry processing technologies, and applications of goji berry-based ingredients in developing functional food products.
\end{abstract}

Keywords: goji; bioactive compounds; antioxidant properties; health benefits; processing; food product development

\section{Introduction}

Berry fruits are frequently consumed worldwide due to their richness in highly valuable bioactive compounds, which potentially positively impact human health [1,2]. In addition to dietary fibers, vitamins, and minerals, berries contain phytochemicals, such as phenolic compounds and carotenoids, which exert antioxidant, anti-inflammatory, and many other health-promoting effects [3]. Berries are consumed fresh, frozen, or dried and used as ingredients in different food products and dietary supplements [4]. As a marketing strategy to promote their extraordinary health benefits, berries are widely advertised as superfruits [5] and functional foods [6]. Among exotic berry fruits, goji berries are gaining more importance in different countries, both from medical and pharmaceutical standpoints, as well as their further application in the food industry.

The genus Lycium (Solanaceae) comprises about 100 species distributed from temperate to subtropical regions [7]. The fruits known as goji berries, wolfberries, barbary wolfberry, and Chinese boxthorn (or gouqizi in Chinese) might derive from two closely related species, Lycium barbarum L. and L. chinense Mill. Lycium barbarum is a perennial deciduous shrub with ellipsoid orange-red berries and a sweet-tangy flavour. The original area is not definitively established, but it could be between Southeast Europe and Southwest Asia. The plant is widely distributed in warm regions, particularly in the Mediterranean, Southwest, and Central Asia. Lycium chinense is native to China, Taiwan, and Japan, and is widely cultivated in Asia, but is also naturalized in Europe and the United States. The black 
goji fruits with a specific composition and taste are obtained from Chinese native species L. ruthenicum Murr. [8-10].

The first reports about goji berries are associated with their use in traditional Chinese medicine in the form of mild Yin tonics, tinctures, and powders [11]. In addition, since ancient times, these berries have been highly valued and used in raw, dried, or processed forms, such as tea, juice, wine, or liqueur [12]. Due to effective instrumental techniques, the complex composition of goji berries has been examined in detail in recent years. It has been shown that goji berries are a good source of nutrients such as lipids, proteins, fibres, vitamin C, and minerals [13,14], and non-nutritive bioactive compounds such as phenolic compounds, polysaccharides, and carotenoids $[15,16]$. On the other hand, in vitro antioxidant assays, in vivo studies, and clinical trials have contributed to understanding some of the health benefits of goji berries [8,16-18]. This knowledge has created a new concept in diets, aiming to develop and promote goji berries as a functional food, or their use in formulating innovative food products. For these reasons, at the beginning of the twenty-first century, goji berry cultivation spread outside China and other Asian countries. Precisely, there are reports that goji berries are cultivated throughout Europe, including in Italy [17,19], Portugal [20], Greece [15,21,22], Romania [16], Bulgaria [23], Serbia [24,25], and North Macedonia [26], as well as Slovenia [2], Switzerland [27], Poland [28], and Lithuania [29]. Despite observed variations in chemical compositions and bioactivities among goji berries from different regions, affected by genotypes, environmental conditions, and many other pre-harvest and post-harvest factors, the specific profile of primary and secondary metabolites and good antioxidant properties makes goji berries convenient for further applications in the pharmaceutical and food industries. Today, goji berries are available as food or food supplements on the global functional food market. In Italy, goji fruit has been added by the Ministry of Health to the list of foods with physiological antioxidant properties, and is commonly found in food supplements. Goji berries are also present in various food products, including in ice-creams, marmalades, sauces, salads, and beer, as well as bakery and dairy products [30]. Although, in general, the goji berry has no long history of significant consumption in Europe, the goji berry is not regulated under the EU novel foods legislation, and has no restrictions or specific legislation requirements for its use and further food applications. Among different identified safety concerns, there is growing evidence that goji berries may trigger allergic reactions in sensitive individuals, especially across Mediterranean populations [31,32].

\section{Nutritional Value and Bioactive Compounds of Goji Berries}

Specific colours, from yellow and red (L. barbarum) to black (L. ruthenicum), as well as a combined sweet, tangy, and pungent taste, make goji berries very attractive to consumers [25]. The balanced content of sugars (fructose, glucose, and sucrose), organic acids, and specific secondary metabolites is responsible for the acceptable sensory characteristics of raw and dried goji berries, as well as for the refreshing character of different food products enriched with them $[12,13,18]$ (Figure 1). In the nutritional term, goji berries present a source of dietary fibres $[13,14,25]$, vitamin C [8,14,24,33,34], and some minerals, including potassium, copper, manganese, iron, and zinc $[13,14,25,26,35]$. In addition, microelements from L. barbarum fruits have high bioaccessibility [36]. The primary fatty acids of goji berries are linoleic acid, followed by oleic, palmitic, and stearic acids (about $95 \%$ of the total fatty acids) $[20,25,26,33,37]$. The most abundant amino acids in goji berries are proline and serine, while the essential amino acids represent up to $30 \%$ of total free amino acids [34]. In addition, goji berries have characterized non-protein amino acids, such as $\gamma$-aminobutyric acid, hydroxyproline, and citrulline, with specific metabolic functions [38]. 


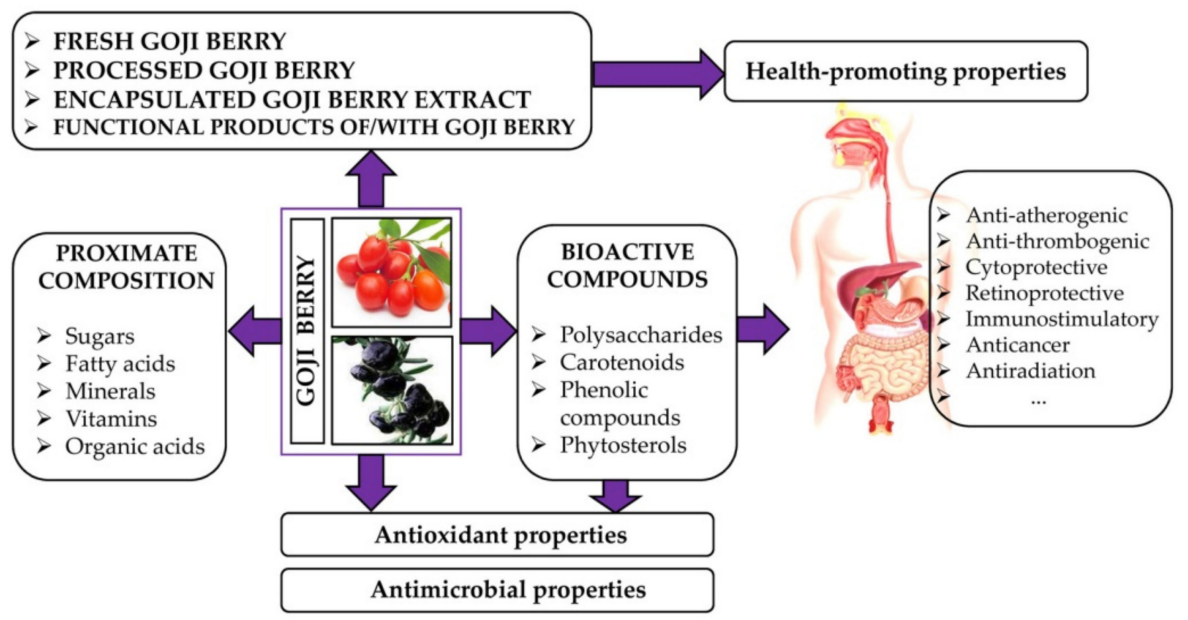

Figure 1. Biological activities of goji berry and its products.

Goji berries exert various biological activities and health benefits, such as antioxidant, anti-inflammatory, antimicrobial, immuno-stimulating, anti-diabetic, neuroprotective, anti-cancer, prebiotic, and anti-obesogenic effects, which have been reviewed by several authors [9,18,39-41] (Figure 1). These beneficial properties are attributed to the individual or combined effects of the constituents of goji berries [18,42]. Water-soluble polysaccharides (L. barbarum polysaccharides, LBPs) are considered to be the most important bioactive components of goji berries [12,43]. In addition to pectic polysaccharides, as major compounds, LBPs are composed of glucan, xylan, and arabinogalactan-proteins [44]. The main chains of the glycan backbones of LBPs are composed of $(1 \rightarrow 3)-\beta$-D-galactopyranosyl, $(1 \rightarrow 6)$ - $\beta$-D-galactopyranosyl, and $(1 \rightarrow 4)$ - $\alpha$-D-galactopyranosyl-uronic acid residues $[45,46]$. The LBPs account for $5-8 \%$ of the dried fruit [12]. In fact, the yield of LBPs was proposed as a parameter to evaluate the quality of L. barbarum and its applicability for medicinal and functional food use [47]. However, structural features including molecular weight, type, and the ratio of monosaccharides, glycosidic linkage patterns, and chain conformations may strongly affect LBPs bioactivities $[45,46,48]$. Based on the investigation of the structure-bioactivity relationship, it is assumed that the immunomodulation effects of LBPs originate from different partial acid and enzymatically hydrolysed fragments $[45,46,49]$. Animal model studies have shown that the oral administration of LBPs $(5,10$, and $20 \mathrm{mg} / \mathrm{kg} /$ day) [50] or goji berry extract [51] improves food conversion rate, reduces body weight, and diminishes insulin resistance. Moreover, in vivo mouse model studies have shown that LBPs at a dose of $0.1 \mathrm{~mL} / 10 \mathrm{~g}$ body weight modulate the immune response and affect the intestinal microbiota, stimulating the growth of some probiotic genera [40]. Goji berries are a good source of phenolic compounds, including phenolic acids, flavonoids, phenylpropanoids, coumarins, lignans, and their derivatives $[8,18,20,51]$, which selectively contribute to their bioactivities [51]. Several studies have shown that the phenolic extracts of goji berries exert good in vitro antioxidant activities and antimicrobial effects against some Gram-negative and Gram-positive bacteria [20,25,52]. In addition to antioxidative properties, L. ruthenicum anthocyanins have demonstrated anti-inflammatory [53,54], antilipidemic [55], and antiobesity properties [56]. While these water-soluble flavonoids are responsible for the purplish-blue colour of black goji berry, high carotenoid content, predominant zeaxanthin, and its esters result in the red-orange colour of red goji berries [57]. Moreover, L. barbarum berries contain a higher zeaxanthin content than other zeaxanthinrich foods, such as egg yolks [58]. Since it accumulates in the retina, the protective effects of goji berry against age-related macular degeneration and cataracts are attributed to the presence of zeaxanthin and its antioxidant properties [12]. Furthermore, goji berries contain monoterpenes (phellandrene, sabinene, terpinene) and vitamins [8]. Moreover, goji berries contain 2-O- $\beta$-D-glucopyranosyl-L-ascorbic acid (AA-2 $\beta \mathrm{G}$ ), which hydrolyses via $\alpha$-glucosidase in the intestinal tract to active L-ascorbic acid [59]. 
However, the nutritional composition, bioactive compound profiles, and biological properties of goji berries largely depend on genotypes, affecting their further applications. For example, while L. barbarum berries had a predominant total carotenoid and AA-2 $\beta$ G, L. barbarum var. auranticarpum (a yellow fruit variety) had high levels of flavonoids and pronounced antimicrobial properties; then, L. ruthenicum berries extract had the highest total phenolic content, and the best antioxidant activity [25]. In addition to genotypic differences $[16,25,60]$, bioactive compounds in goji berries are affected by geographic origin [17,38], harvesting time [26,61], and post-harvesting factors [62]. Table 1 summarises recently reported data on the total phenolics, flavonoids, carotenoid and polysaccharides content in red and black goji berries.

Table 1. The total content of phenolics, flavonoids, carotenoids, and polysaccharides in goji berries.

\begin{tabular}{|c|c|c|c|c|}
\hline TPC (mg/g) & TFC (mg/g) & TCC (mg/g) & LBP (mg/g) & Reference \\
\hline \multicolumn{5}{|c|}{ L. barbarum } \\
\hline $2.56-2.82$ & - & 5.7 & - & [8] \\
\hline $11.6-15.7$ & - & - & - & [16] \\
\hline $4.0-13.0$ & - & $4.0-9.5$ & - & [21] \\
\hline 7.17 & 2.37 & 0.43 & - & [24] \\
\hline 1.62 & 2.14 & 0.42 & - & [25] \\
\hline $3.89-8.20$ & - & 2.9 & - & [26] \\
\hline $0.71-2.94$ & - & - & - & [27] \\
\hline $0.25-1.93$ & - & $0.66-4.13$ & - & [28] \\
\hline 7.6 & - & - & - & [33] \\
\hline \multirow{2}{*}{$6.9-8.25$} & $3.18-6.14$ & $12.93-25.35$ & $23.62-42.45$ & [38] \\
\hline & & & $16-48$ & [47] \\
\hline $30.3-73.4$ & $38.5-54.7$ & $3.64-11.33$ & $55.9-62.7$ & [60] \\
\hline $6.9-10.9$ & - & - & - & [61] \\
\hline $2.17-4.48$ & $2.67-3.16$ & $0.21-0.23$ & - & [63] \\
\hline $8.36-14.13$ & - & $0.42-1.01$ & - & [64] \\
\hline $8.16-9.04$ & $1.78-2.63$ & - & - & [65] \\
\hline $3.45-3.47$ & $2.20-2.23$ & - & - & [66] \\
\hline $0.01-5.47$ & - & - & - & {$[67]$} \\
\hline \multicolumn{5}{|c|}{ L. ruthenicum } \\
\hline 2.96 & 0.27 & nd ${ }^{1}$ & - & [25] \\
\hline 26.9 & 36.1 & 0.40 & $56.1^{2}$ & [60] \\
\hline $7.26-9.01$ & $9.77-12.32$ & $0.001-0.003$ & - & [63] \\
\hline $3.44-6.45$ & $5.66-11.16$ & - & - & [66] \\
\hline $21.14-28.52$ & $1.23-1.38$ & - & - & [68] \\
\hline 49.07 & - & - & - & [69] \\
\hline
\end{tabular}

${ }^{1}$ nd-not detected; TPC — total phenolic content; TFC —-total flavonoid content; TCC—-total carotenoid content; LBP-L. barbarum polysaccharides content; ${ }^{2}$ LRP — L. ruthenicum polysaccharides content.

\section{Antioxidant Properties of Goji Berries}

The goji berry is unique in its types and its overall content of bioactive compounds [5]. Compared to other common fruits, goji berry presented less antioxidant capacity than blackcurrant and blueberry, but more than kiwifruit, raspberry, and orange [8]. In addition, several studies indicate that black goji berries have more potent antioxidant properties than red goji berries $[25,63,66,70]$ (Figure 1). The antioxidant activities of goji berries are closely associated with the presence of polysaccharides, carotenoids, flavonoids, and AA-2 $\beta$ G [71] These compounds can exhibit antioxidant effects in several ways: radical scavenging activities toward reactive species via hydrogen atom transfer or electron donation, through metal chelation, or interactions with other antioxidants [72].

The antioxidant effect of flavonoids is influenced by the number of hydroxyl groups on the B ring of their structure. Flavonoids with two hydroxyl groups in the B ring with ortho arrangement had higher scavenging activity. Moreover, due to higher molecule flexibility, flavonoids with single bonds between C2 and C3 showed better antioxidant ability than 
structures with double bonds. In addition to radical scavenging activities, flavonoids exhibit metal ion chelating and reducing ability [20,72]. Anthocyanins donate hydrogen atoms to highly reactive free radicals and block free radical chain reactions. Similar to other flavonoids, the scavenging activity of anthocyanins correlates with the number of hydroxyl groups. Different phenolic compounds in goji berry can have synergistic, additive, or rarely antagonistic antioxidant effects. These interactions are usually concentration-dependent, and are likely due to how phenolic compounds interact with different free radicals. In addition, flavonoids and other phenolics could increase the expression of antioxidant enzymes, such as catalase, glutathione peroxidase, and superoxide dismutase (SOD), and suppress the formation of reactive oxygen species $[9,18,19,69]$. Due to the highest phenolic content, the pulp of goji berries has the highest contribution rate to antioxidant capacities compared to seeds and whole fruits [66].

Goji polysaccharides (LBPs) exhibited anti-lipid peroxidation activity, reducing capacity and radical scavenging activity towards the superoxide anion. The activity was similar to those of the synthetic antioxidant, butylated hydroxytoluene (BHT) [9]. Lin et al. (2009) evaluated the antioxidant activity of neutral polysaccharides (LBPN) and three acidic polysaccharides isolated from goji berry, and compared with crude polysaccharide (CP), crude extract of polysaccharide (CE), deproteinated polysaccharide (DP), and deproteinated and dialyzed polysaccharide (DDP). Except for CE and DDP, most polysaccharide fractions at high concentrations exert effective scavenging radical activities. DDP and CE demonstrated lower reducing power, while LBPN and CE showed poor metal ion chelating activity compared to other polysaccharide fractions [73]. Similarly, Wang et al. (2010) demonstrated a poor ferrous ion-chelating effect for LBPN and CE, whereas moderate chelating activities were noticed for CP and acidic polysaccharides [74]. The ability of the carboxyl group from galacturonic acid to scavenge radicals and chelate metal ions contributes a better antioxidant effect of acidic polysaccharides than neutral polysaccharides [73-75]. It is also supposed that LBPs bind low molecular weight phenolic compounds during extraction from raw materials, which contributes to their antioxidant properties [76].

AA- $2 \beta$ G is also an important antioxidant compound of goji berries, which may share similar but distinct mechanistic properties with L-ascorbic acid [77].

Due to the structural diversity of bioactive compounds and their various mechanisms of antioxidant action, different methods have been used to determine the antioxidant activities of goji berry. Among others, the most frequently applied assays include 2,2-diphenyl-1-picrylhydrazyl(DPPH)radical,2,2' -azino-bis(3-ethylbenzothiazoline-6sulphonic acid) (ABTS) radical cation scavenging activity, ferric reducing antioxidant power (FRAP), cupric ion reducing antioxidant capacity (CUPRAC), oxygen radical absorbance capacity (ORAC), and $\beta$-carotene bleaching inhibition.

In fact, in vitro studies have found a strong correlation between polysaccharides and phenolics with antioxidant activities $[20,60,66,78]$, supporting that these compounds are the most significant contributors to the total antioxidant activities of goji berries [60]. On the other hand, the absence of a significant correlation between in vitro antioxidant activities (DPPH ${ }^{\bullet}, \mathrm{ABTS}^{\bullet+}$, and FRAP assays) and total carotenoids [60] could be explained by a lack of the enzyme which is capable of hydrolysing zeaxanthin esters to free zeaxanthin [79]. However, the abilities of goji berry extract to inhibit lipid peroxidation in the $\beta$-carotene-linoleic acid assay are linked to carotenoids content $[17,25]$. Namely, the presence of a long chain of conjugated double bonds in carotenoids was attributed to their more distinct effect in scavenging hydroxyl radicals compared to other bioactive compounds [74]. Furthermore, among carotenoids, there is evidence that zeaxanthin has the highest hydroxyl radical-scavenging activity hydroxyl radical-scavenging activities, followed by $\beta$-carotene, lycopene and lutein [80].

In addition to genetic differences, reports on the antioxidant activities of goji berries reflect differences in bioactive compounds affected by environmental conditions in various geographical regions, and extraction methods, among many others (Table 2). 
Table 2. Antioxidant properties of goji berries.

\begin{tabular}{|c|c|c|c|c|c|}
\hline Sample Origin & Extraction Solvent & DPPH• & $\mathrm{ABTS}^{\bullet+}$ & FRAP & Reference \\
\hline \multicolumn{6}{|c|}{ L. barbarum } \\
\hline \multirow{3}{*}{ China } & \multirow{3}{*}{$\begin{array}{c}\text { ethanol }(60 \%, v / v) \\
\text { methanol }(80 \%, v / v) \\
\text { Acetone/water/acetic acid } \\
(70: 29.5: 0.5)\end{array}$} & $44.63-47.63 \%$ & - & $0.15-0.17 \mu \mathrm{mol} \mathrm{Fe} e^{+2} / \mathrm{g}$ & {$[66]$} \\
\hline & & 35.88-85.46 $\mu \mathrm{mol} \mathrm{TE} / \mathrm{g}$ fw & 59.3-95.6 $\mu \mathrm{mol} \mathrm{TE} / \mathrm{g} \mathrm{fw}$ & 57.7-92.5 $\mu \mathrm{mol} \mathrm{TE} / \mathrm{g} \mathrm{fw}$ & [60] \\
\hline & & 16.07-17.47 $\mu \mathrm{mol} \mathrm{TE/g}$ & $53.92-64.38 \mu \mathrm{mol} \mathrm{TE} / \mathrm{g}$ & $26.39-46.51 \mathrm{mmol} \mathrm{Fe}^{+2} / \mathrm{g}$ & {$[63]$} \\
\hline Greece & $\begin{array}{l}\text { water } \\
\text { water }\end{array}$ & $\begin{array}{l}1.29-3.00 \mathrm{mg} / \mathrm{mL}(\mathrm{IC} 50) \\
0.83-1.15 \mathrm{mg} / \mathrm{mL}(\mathrm{IC} 50)\end{array}$ & $\begin{array}{c}0.42-1.10 \mathrm{mg} / \mathrm{mL} \text { (IC50) } \\
0.19-0.4 \mathrm{mg} / \mathrm{mL} \text { (IC50) }\end{array}$ & $\begin{array}{l}- \\
-\end{array}$ & $\begin{array}{l}{[22]} \\
{[61]}\end{array}$ \\
\hline Italy & $\begin{array}{l}\text { methanol: water } \\
\text { acidified with HCL }\end{array}$ & 等 & - & $18.00-20.89 \mu \mathrm{mol} \mathrm{Fe}^{+2} / \mathrm{g} \mathrm{fw}$ & [8] \\
\hline $\begin{array}{l}\text { North } \\
\text { Macedonia }\end{array}$ & water & $1.51-6.25 \mathrm{mg} / \mathrm{g} \mathrm{dw}$ & $1.94-9.93 \mathrm{mg} / \mathrm{g} \mathrm{dw}$ & - & [26] \\
\hline Poland & $\begin{array}{c}\text { methanol }(80 \%, v / v)+ \\
1 \% \mathrm{HCl}\end{array}$ & 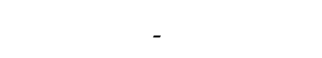 & 16.0-68.3 $\mu \mathrm{mol} \mathrm{TE/g}$ & $14.4-63.0 \mu \mathrm{mol} \mathrm{TE} / \mathrm{g}$ & [28] \\
\hline Portugal & methanol $(80 \%, v / v)$ & $6.25 \mathrm{mg} / \mathrm{mL}$ (EC50) & \multirow{2}{*}{$2486-2512 \mathrm{mg} T E / \mathrm{g}$} & \multirow{2}{*}{ 16.91-19.52 $\mathrm{mg} \mathrm{TE} / \mathrm{g}$} & {$[20]$} \\
\hline Romania & methanol $(70 \%, v / v)$ & \multirow{2}{*}{$\begin{array}{l}8.79-9.35 \mathrm{mg} \mathrm{TE} / \mathrm{g} \\
4.52 \mu \mathrm{mol} \mathrm{TE} / \mathrm{g} \text { fw }\end{array}$} & & & \multirow{2}{*}[16]{} \\
\hline Serbia & methanol $(80 \%, v / v)$ & & $0.12 \mu \mathrm{mol} \mathrm{TE} / \mathrm{g}$ fw & $5.32 \mu \mathrm{mol} \mathrm{TE} / \mathrm{g} \mathrm{fw}$ & \\
\hline Switzerland & methanol & \multirow{3}{*}{$\begin{array}{l}22.64 \mathrm{mg} / \mathrm{mL}(\mathrm{EC} 50) \\
18.19 \mathrm{mg} / \mathrm{mL}(\mathrm{EC} 50)\end{array}$} & $6.94-13.22 \mu \mathrm{mol} \mathrm{TE} / \mathrm{g} \mathrm{dw}$ & \multirow{2}{*}{$293 \mathrm{mMFe}^{+2}$} & \multirow{2}{*}[27]{} \\
\hline \multirow{2}{*}{ Turkey } & water & & - & & \\
\hline & methanol $(80 \%, v / v)$ & & - & $2.62 \mathrm{mM} \mathrm{Fe}^{+2}$ & {$[65]$} \\
\hline \multicolumn{6}{|c|}{ L. ruthenicum } \\
\hline \multirow{4}{*}{ China } & ethanol $(85 \%, v / v)$ & \multirow{3}{*}{$\begin{array}{c}315.7-460.5 \mu \mathrm{mol} \mathrm{TE} / \mathrm{g} \mathrm{dw} \\
63.09-85.15 \% \\
49.65 \mu \mathrm{mol} \mathrm{TE} / \mathrm{g} \mathrm{fw}\end{array}$} & \multirow{3}{*}{$\begin{array}{c}327.8-485.6 \mu \mathrm{mol} \mathrm{TE} / \mathrm{g} \mathrm{dw} \\
- \\
47.8 \mu \mathrm{mol} \mathrm{TE} / \mathrm{g} \mathrm{fw}\end{array}$} & \multirow{3}{*}{$\begin{array}{c}\text { 377.0-539.4 } \mu \mathrm{mol} \mathrm{TE} / \mathrm{g} \mathrm{dw} \\
0.55-0.62 \mu \mathrm{mol} \mathrm{Fe}+2 / \mathrm{g} \\
56.3 \mu \mathrm{mol} \mathrm{TE} / \mathrm{g} \mathrm{fw}\end{array}$} & \multirow{3}{*}{$\begin{array}{l}{[70]} \\
{[66]} \\
{[60]}\end{array}$} \\
\hline & ethanol $(60 \%, v / v)$ & & & & \\
\hline & methanol $(80 \%, v / v)$ & & & & \\
\hline & $\begin{array}{l}\text { acetone/water/ acetic } \\
\text { acid (70:29.5:0.5) }\end{array}$ & 32.29-35.86 $\mu \mathrm{mol} \mathrm{TE/g}$ & $147.00-180.03 \mu \mathrm{mol} \mathrm{TE} / \mathrm{g}$ & $278.21-363.46 \mathrm{mmol} \mathrm{Fe}^{+2} / \mathrm{g}$ & {$[63]$} \\
\hline Serbia & methanol $(80 \%, v / v)$ & $10.22 \mu \mathrm{mol} \mathrm{TE} / \mathrm{g} \mathrm{fw}$ & $0.28 \mu \mathrm{mol} \mathrm{TE} / \mathrm{g}$ fw & $19.43 \mu \mathrm{mol} \mathrm{TE} / \mathrm{g} \mathrm{fw}$ & [25] \\
\hline
\end{tabular}

TE-Trolox equivalent; fw-fresh weight; dw-dry weight.

\section{Health Benefits and Side Effects of Goji Berry Consumption}

\subsection{Health Benefits of Goji Berry Consumption}

The global popularization of goji berry and goji berry-based products is supported by scientific evidence on their health-promoting effects (Figure 1). In general, LBPs, zeaxanthin dipalmitate, vitamins, betaine, and mixed extracts have been attributed to the anti-aging, improving eyesight, anti-fatigue, and other beneficial effects of goji berry described in ancient herbals [7]. The main findings from human intervention studies demonstrating the health properties of goji berry, juice, or extracts are summarized in Table 3.

Table 3. Clinical studies on the effects of goji berries and their products.

\begin{tabular}{|c|c|c|c|c|c|}
\hline Study Design & Study Population & Number & Intervention (Dose) & Main Outcomes & Reference \\
\hline $\begin{array}{c}\text { Single-blinded, } \\
\text { placebo-controlled, parallel } \\
\text { design study }\end{array}$ & Healthy adults & 27 & $\begin{array}{c}28 \text { days }(15 \mathrm{~g} / \mathrm{d} \\
\text { wolfberries-estimated to } \\
\text { provide } \sim 3 \mathrm{mg} / \mathrm{d} \\
\text { esterified zeaxanthin })\end{array}$ & $\begin{array}{l}\text { plasma zeaxanthin increased } \\
2.5 \text {-fold }\end{array}$ & [81] \\
\hline $\begin{array}{l}\text { Double-blinded, } \\
\text { placebo-controlled RCT }\end{array}$ & Healthy adults & 34 & $\begin{array}{l}14 \text { days }(120 \mathrm{~mL} / \mathrm{d} \text { LBP } \\
\text { standardized } \\
\text { juice-equivalent at least } \\
150 \mathrm{~g} \text { of fresh fruit) }\end{array}$ & $\begin{array}{c}\uparrow \text { subjective feelings of } \\
\text { general well-being, } \\
\text { neurologic/psychologic } \\
\text { performance and } \\
\text { gastrointestinal functions }\end{array}$ & [82] \\
\hline $\begin{array}{c}\text { Double-blinded, } \\
\text { placebo-controlled RCT }\end{array}$ & Healthy adults & 39 & $\begin{array}{c}30 \text { days }(120 \mathrm{~mL} / \mathrm{d} \\
\text { LBP-standardized juice })\end{array}$ & $\begin{array}{c}\uparrow \text { SOD, GSH-Px } \\
\downarrow \text { lipid peroxidation (MDA) }\end{array}$ & [83] \\
\hline $\begin{array}{l}\text { Parallel design } \\
\text { intervention study }\end{array}$ & Healthy elderly subjects & 177 & 3 months (LBPs) & $\begin{array}{c}\downarrow \text { plasma triglycerides, total } \\
\text { cholesterol, and LDL } \\
\text { cholesterol } \\
\uparrow \text { HDL cholesterol }\end{array}$ & {$[84]$} \\
\hline $\begin{array}{c}\text { Double-blinded, } \\
\text { placebo-controlled RCT }\end{array}$ & Older healthy adults & 60 & $\begin{array}{l}30 \text { days }(120 \mathrm{~mL} / \mathrm{d} \text { LBP } \\
\text { standardized } \\
\text { juice-equivalent at least } \\
150 \mathrm{~g} \text { of fresh fruit) }\end{array}$ & $\begin{array}{l}\uparrow \text { several immunological } \\
\text { responses and subjective } \\
\text { feelings of general } \\
\text { well-being }\end{array}$ & [85] \\
\hline $\begin{array}{c}\text { Double-blinded, } \\
\text { placebo-controlled RCT }\end{array}$ & Healthy adults & 28 & $\begin{array}{l}14 \text { days }(120 \mathrm{~mL} / \mathrm{d} \text { LBP } \\
\text { standardized } \\
\text { juice-equivalent at least } \\
150 \mathrm{~g} \text { of fresh fruit) }\end{array}$ & $\downarrow$ waist circumference & [86] \\
\hline
\end{tabular}


Table 3. Cont.

\begin{tabular}{|c|c|c|c|c|c|}
\hline Study Design & Study Population & Number & Intervention (Dose) & Main Outcomes & Reference \\
\hline $\begin{array}{l}\text { Double-blinded, } \\
\text { placebo-controlled RCT }\end{array}$ & Healthy elderly subjects & 150 & $\begin{array}{l}90 \text { days }(13.7 \mathrm{~g} / \mathrm{d} \\
\text { milk-based formulation of } \\
\text { goji berry, LWB })\end{array}$ & $\begin{array}{l}\uparrow \text { plasma zeaxanthin and } \\
\text { antioxidant levels protects } \\
\text { from hypopigmentation and } \\
\text { soft drusen accumulation in } \\
\text { the macula of elderly subjects }\end{array}$ & [87] \\
\hline $\begin{array}{c}\text { Double-blinded, } \\
\text { placebo-controlled RCT }\end{array}$ & Healthy elderly subjects & 150 & $\begin{array}{l}90 \text { days }(13.7 \mathrm{~g} / \mathrm{d} \\
\text { milk-based formulation of } \\
\text { goji berry, LWB })\end{array}$ & $\begin{array}{l}\uparrow \text { postvaccination serum } \\
\text { influenza-specific } \\
\text { immunoglobulin G levels } \\
\text { and seroconversion rate }\end{array}$ & [88] \\
\hline $\begin{array}{c}\text { Double-blinded, } \\
\text { placebo-controlled RCT }\end{array}$ & Type 2 diabetes patients & 67 & 90 days (300 mg LBPs/d) & $\begin{array}{c}\downarrow \text { glucose and } \uparrow \\
\text { insulinogenic index } \uparrow \mathrm{HDL} \\
\text { cholesterol }\end{array}$ & [89] \\
\hline $\begin{array}{l}\text { Double-blinded, } \\
\text { placebo-controlled RCT }\end{array}$ & $\begin{array}{l}\text { Healthy overweight and } \\
\text { mild } \\
\text { hypercholesterolemic subjects }\end{array}$ & 53 & $\begin{array}{c}8 \text { weaks }(80 \\
\mathrm{mL} / \text { pouch-contained } \\
13.5 \mathrm{~g} \text { of } \mathrm{WBE})\end{array}$ & $\begin{array}{c}\text { anti-oxidative and } \\
\text { anti-inflammatory effects by } \\
\text { modulating mRNA } \\
\text { expression }\end{array}$ & [90] \\
\hline Parallel design RCT & Metabolic syndrome patients & 50 & $\begin{array}{l}45 \text { days ( } 14 \mathrm{~g} \text { dried goji } \\
\text { berry with healthy dietary } \\
\text { pattern) }\end{array}$ & $\begin{array}{c}\downarrow \text { transaminases and waist } \\
\text { circumference } \\
\uparrow \text { serum antioxidant capacity } \\
\text { and GSH } \\
\downarrow \text { lipid peroxidation }\end{array}$ & [91] \\
\hline $\begin{array}{l}\text { Double-blinded, } \\
\text { placebo-controlled RCT }\end{array}$ & Retinitis pigmentosa (RP) & 42 & $\begin{array}{l}12 \text { months ( } 10 \mathrm{~g} \text { of } \mathrm{LB} \\
\text { granules/d, estimated to } \\
\text { provide } 0.175 \mathrm{~g} \text { LBPs })\end{array}$ & $\begin{array}{l}\text { LB supplement provides a } \\
\text { neuroprotective effect for the } \\
\text { retina and could help delay } \\
\text { or minimize } \\
\text { cone degeneration in RP }\end{array}$ & [92] \\
\hline Double-blind crossover RCT & Healthy, overweight men & 17 & $25 \mathrm{~g}$ of dried LB fruit & $\begin{array}{c}\neq \text { postprandial energy } \\
\text { expenditure, substrate } \\
\text { oxidation, and markers for } \\
\text { lipid and glucose } \\
\text { metabolism }\end{array}$ & [93] \\
\hline Parallel design RCT & $\begin{array}{l}\text { Middle-aged and } \\
\text { older adults }\end{array}$ & 40 & $\begin{array}{l}16 \text { weak ( } 15 \text { g/d whole, } \\
\text { dried wolfberry with } \\
\text { healthy dietary pattern) }\end{array}$ & $\begin{array}{c}\text { improves vascular tone } \\
\downarrow \text { lipid peroxidation } \\
\text { (8-iso-prostaglandin F2 } \alpha \text { ) }\end{array}$ & {$[94,95]$} \\
\hline Parallel design RCT & $\begin{array}{l}\text { Healthy, middle-aged } \\
\text { subjects }\end{array}$ & 27 & $\begin{array}{l}3 \text { months ( } 25 \mathrm{~g} \text { of whole } \\
\text { goji berries or supplements } \\
\text { of lutein and zeaxhantin) }\end{array}$ & $\begin{array}{c}\uparrow \text { macular pigment optical } \\
\text { density }\end{array}$ & [96] \\
\hline
\end{tabular}

RCT-randomized control trial; RP-retinitis pigmentosa; LB-L.barbarum; LBPs-L.barbarum polysaccharides; LWB-Lacto-Wolfberry; SOD—superoxide dismutase; GSH-Px—glutathione peroxidase; MDAmalondialdehyde; LDL-low density lipoprotein; HDL—high density lipoprotein; WBE-aqueous extract of wolfberry; GSH-glutathione.

In 2008, the first randomized, double-blind, placebo-controlled clinical study was conducted, which reported the general effects of goji juice in healthy adults outside of China [82]. Participants in the intervention group consumed $120 \mathrm{~mL} /$ day of commercial goji juice (GoChi), standardized to contain LBP equivalent in at least $150 \mathrm{~g}$ of fresh fruit. Consistent with traditional use, the main beneficial effects observed in the intervention group after 14 days included increasing general well-being and improving neurologi$\mathrm{cal} /$ psychologic performances and gastrointestinal functions. Other studies demonstrated that the 30-day daily consumption of GoChi led to the improvement of endogenous antioxidant enzyme activities, along with a decrease in malondialdehyde (MDA), an oxidative stress marker [83], and an increase in lymphocyte, IgG, and IL-2 levels in healthy subjects, without adverse effects [85]. In addition, it was found that GoChi consumption for 14 days increases metabolic rate and reduces the waist circumference in healthy subjects of both sexes [86].

As $\mathrm{Yu}, \mathrm{Wu}$, and Niu (2009) demonstrated, LBP extract exhibited favourable effects on plasma lipids and the risk of cardiovascular diseases to the elderly [84]. In addition, based on the observed hypoglycemic activities and increased HDL concentration, after three months of supplementation (300 $\mathrm{mg} /$ day), LBP has been considered as a prominent adjuvant therapy for patients with type 2 diabetes [89]. Although several mechanisms may account for these effects, there is a finding that the water goji berries extract exerted antioxidative and anti-inflammatory effects by controlling the expression of inflammatory 
mRNAs in overweight and hypercholesterolemia-suffering subjects [90]. In another study, the inclusion of $14 \mathrm{~g}$ of dried goji berry as part of a healthy diet after 45 days was associated with a significant reduction in transaminases and waist circumference, improved lipid profile, and oxidative stress parameters in patients with metabolic syndrome [91]. However, a meta-analysis of the effects of $L$. barbarum supplementation on cardiometabolic risk factors, which included 548 subjects, indicated only a favourable effect on glucose control, and a marginal reduction in total cholesterol and triglyceride levels, without any benefit to body weight and blood pressure [97]. Moreover, a single dose of $25 \mathrm{~g}$ of dried L. barbarum fruits did not influence the postprandial energy expenditure, plasma glucose, serum-free fatty acids, and triglycerides concentrations in healthy, overweight men [93].

According to Cheng et al. (2005), dietary supplementation with whole dried goji berry ( $15 \mathrm{~g} /$ day), estimated to contain $3 \mathrm{mg}$ zeaxanthin, resulted in a 2.5-fold increase of plasma zeaxanthin. Based on this result, goji berry has been proposed as an inexpensive, effective, and safe food dietary strategy to increase plasma zeaxanthin concentration [81]. A recent study showed that 90 days of goji berry consumption was accompanied by an increase in macular pigment optical density, a marker of age-related macular degeneration in healthy, middle-aged adults [96]. Other studies demonstrated that dietary intervention with a proprietary milk-based formulation of goji berry (13.7 g/day), with enhancing zeaxanthin bioavailability [98], for 90 days, increases plasma zeaxanthin and improves antioxidant capacity and macular characteristics [87], as well as enhancing the immune system in healthy elderly subjects [88]. Moreover, the retinoprotective effects of 12 -month goji berry supplementation were proven in patients with retinitis pigmentosa [92]. Thus, goji berry supplementation may represent a model of the successful integration of traditional Asian practices into Western medicine related to the prevention and treatment of retinal disorders [99].

Due to limited evidence on the health effects of whole dried fruits, considering possible synergism among bioactive compounds, Toh et al. (2021) investigated the effects of healthy dietary patterns, either with or without whole dried wolfberry $(15 \mathrm{~g} / \mathrm{d})$, in middle-aged and older adults. They demonstrated that adherence to a healthy dietary pattern based on whole grains, fruits, non-starchy vegetables, and non-processed meats improves vascular tone, while incorporating goji berry into the diet further improves the blood lipid-lipoprotein profile, and may lower long-term cardiovascular risk [94]. In addition, they observed an inverse association between the changes in plasma zeaxanthin and plasma 8-iso-prostaglandin F2 $\alpha$. Therefore, goji berry within a healthy dietary pattern is proposed as a dietary strategy to attenuate lipid peroxidation among middle-aged and older adults, with a heightened risk of oxidative stress-induced age-related disorders [95].

Furthermore, a recent meta-analysis of goji berry-based RCTs indicated more pronounced effects of whole goji berry versus goji berry extract in improving the blood lipids and lipoproteins profile, supporting its incorporation into dietary patterns targeted at improving cardiovascular health [100].

Overall, findings from human interventional studies support the health benefits of goji berry consumption with the dosages used in traditional medicine, which range from 6-30 $\mathrm{g}$ of dried whole goji berry [12].

\subsection{Side Effects of Goji Berry Consumption}

Based on long-term traditional use over 2500 years, goji berry is now generally recognized as a non-toxic food $[9,12]$. Additionally, findings from dietary interventional studies indicate the safety of goji berry and its products when taken within traditionally established doses. However, some concerns about goji berries have been raised, especially regarding their consumption in large amounts. However, studies evaluating adequate dosage regimens, adverse reactions, and the long-term safety of goji berries and their products are scarce [12]. The oral administration of goji juice (GoChi) in rats demonstrated no toxicity, even at the maximum dose $(10 \mathrm{~mL} / \mathrm{kg} /$ day) [101]. However, high concentrations of goji juice should be carefully consumed, due to recently observed pro-oxidant effects 
and reducing the lifespan of the nematode Caenorhabditis elegans, a model organism for in vivo tests [102]. There are also reported cases of hepatotoxicity related to consuming goji berry $[103,104]$.

Other risks related to goji berry include the presence of tropane alkaloids [9], chemical contaminants, such as pesticides and toxic elements $[105,106]$, or some proteins that can cause allergic reactions in sensitive consumers [31]. However, it has been shown that the organic production system has a significant influence on the lower content of toxic elements [13], and the low contents of tropane alkaloids and pesticides, in general, have no toxicological relevance $[9,106,107]$. A recent study reported that the exposure of the dangerous effects of chemical residues is more likely from goji berries obtained from plantations than from goji berries from supermarkets, and that metal exposure is more dangerous than pesticide exposure [106].

Since the goji berry was introduced into the European market as a functional food and a nutraceutical a few years ago, its consumption has significantly increased. However, there is evidence from several countries that its consumption might lead to hypersensitive reactions. A 53-year-old male developed systemic photosensitivity due to the simultaneous prolonged use of goji berries and cat's claw for 5 and 3 months, respectively. However, furthermore, the photo-provocations test revealed that photosensitivity is accompanied only by goji berry [108]. There is evidence that goji berries can cause allergic reactions in exposed and unexposed food-allergic individuals [109]. In addition, two cases of anaphylaxis were reported [110,111]. Cross-reactivity was demonstrated with peach, tomato, tobacco, a mixture of nuts, and Artemisia sp. pollen, while lipid transfer proteins (LTPs) are recognised as the major allergens involved in sensitisation and cross-reactivity $[109,112]$. Therefore, a high-cross reactivity with other frequently consumed foods could explain the high prevalence rate and the low frequency of clinical symptoms of goji berry allergies among European populations [31].

In addition, there is a risk of possible interactions between goji berry and medicines. There is evidence that the concomitant use of Lycium fruit tea, juice, and wine with oral anticoagulants, such as warfarin, might increase the risk of bleeding [113]. In a recent case report, Guzman et al. (2021) described the toxicity of the antiarrhythmic drug flecainidine in a 75-year-old female associated with goji berry tea consumption as a self-medication practice for the prevention of COVID-19 [114].

\section{Processing of Goji Berries}

\subsection{Oven and Freeze-Drying Dehydration Techniques}

Dehydration is one of the most commonly used processes for extending the shelf life of fruit, and it is based on the simultaneous transfer of heat and mass. Solar drying is a traditional drying method for goji berries. However, this type of drying and environmental conditions can cause a loss of fruit quality. In recent years, oven-air, freeze, or advanced drying techniques have been increasingly used for goji berries dehydration, thus preventing enzyme activity, reducing microbiological spoilage, and minimizing adverse reactions during storage [115]. However, drying goji berries is difficult due to the wax layer surrounding the peel of the berries, which impedes the diffusion of water from berries [115,116]. In addition, the wax layer of goji berries requires high temperatures and extended treatment, which can negatively affect the content of high-value compounds.

Thus, several studies have examined the possibility of using pre-treatment before drying, intending to speed up the drying process, reduce energy consumption, and improve the quality of dried products [115-120]. For example, abrasive pre-treatment in a motorized drum coated with sandpaper was used to carefully remove wax from the surface of goji berries, which shortened the drying time in the convective oven at $60{ }^{\circ} \mathrm{C}$, preserved colour, increased antioxidant properties, and maintained the sugar content of berries [115,117,119]. In addition, washing and soaking goji berries in sodium carbonate solution before hot air drying increased the effective diffusivity and reduced the drying time; that is, it increased the content of bioactive compounds (total phenolics, flavonoids, 
carotenoids, and betaine) and improved the antioxidant activities of goji berries dried at $40{ }^{\circ} \mathrm{C}$ and $50{ }^{\circ} \mathrm{C}$ [120]. Moreover, sodium carbonate pre-treatment combined with hybrid drying techniques increased the pore size of goji berries, which accelerated the drying process and improved heat and mass transfer [121].

Pre-treatments, such as osmotic dehydration $\left(60 \mathrm{~min}, 55^{\circ} \mathrm{C}\right)$ and combined effect pulsed electric field and osmotic dehydration, have led to a decrease in drying time for the goji berry, maintaining its bright red colour, improving its texture, retaining its high antioxidant potential, and prolonging shelf life during the storage of dried goji berries [122,123]. The application of pulsed electric fields in pre-treatment affected the permeabilization of the tissue of goji berries, which increased the mass transfer during subsequent osmotic dehydration and air-drying [122]. The most conventional techniques use high drying temperatures, which most often impair the quality of the product (colour, taste, aroma, and texture), prevent rehydration, generate a Maillard reaction, and contribute to forming a hard coat around the berry [124]. However, although the texture of oven-dried goji berries is often disturbed, they are a good source of bioactive compounds such as phenolics, and show antioxidant activity [105,125].

On the other hand, quick-freezing using liquid nitrogen at $-80{ }^{\circ} \mathrm{C}$ proved to be the most suitable freezing process for goji berries in comparison with other freezing temperatures at -60 and $-100{ }^{\circ} \mathrm{C}$, because, at this temperature, goji berries retain good sensory properties, have the lowest activity of polyphenol peroxidase, and more negligible damage of the internal structures of epidermal cells [126]. Furthermore, the advanced freeze-drying technique contributes to preserving goji berries' bioactive compounds (phenolic acids, vitamin C, monoterpenes, and carotenoids) and nutrients. This results in high-quality, dried goji snacks which are light, crunchy, with original taste, preserved texture, and a healthy alternative to sweet snacks $[124,127,128]$. In addition, Song et al. (2018) reported that the application of advanced freeze-dried with instant controlled pressure drop drying for the dehydration of goji berries resulted in excellent crispness and texture, as well as high contents of total polysaccharides $(139.8 \mathrm{~g} / \mathrm{kg})$ and carotenoids $(2.43 \mathrm{~g} / \mathrm{kg})$ in dried products [121].

\subsection{Advanced Techniques}

In recent years, the effect of novel pre-treatments and the possibility of applying advanced techniques for drying goji berries have been increasingly examined. The recently developed cold plasma pre-treatment applied to goji berries has significantly reduced drying time, improved rehydration, and maintained the colour of berries [129]. After pre-treatment with cold plasma, the cell walls of the goji berries become thinner and more permeable, affecting the loss of bioactive compounds, probably degraded after interaction with charged particles generated by cold plasma during long treatment [129]. The electrohydrodynamic drying technique (EHD) has been successfully applied for the dehydration of goji berries, previously pre-treated with alkaline solution ( $\mathrm{KOH}$ and $\mathrm{NaOH})$, $\mathrm{Na}_{2} \mathrm{CO}_{3}$, sucrose ester, and ultrasonic. All applied pre-treatments accelerated drying, reduced drying time, affected energy savings, maintained good berry quality, and changed the surface microstructure of goji berries. However, only alkaline pre-treatment can be used as an optimal pre-treatment for the industrial application of goji berries dried using EHD [118].

Infrared drying has been successfully used for drying various fruit and vegetables, but this type of drying is not suitable for products sensitive to heat, so it is often combined with other drying methods [130]. Till now, far-infrared radiation heating assisted pulsed vacuum drying (FIR-PVD) [131], and a pilot-scale pulsed vacuum infrared drying system (PVID) [132] was used to dry goji berries. Both infrared-based drying techniques significantly reduced drying time and increased drying efficiency; that is, the goji berries had a more sustainable and attractive colour compared to hot air-dried berries. In addition, porous and fissured microstructures were observed in berries that were dried using FIR-PVD, and can potentially improve drying kinetics and rehydration [132]. Finally, the 
most favourable conditions for drying goji berries are a drying temperature (infrared heating) of $65{ }^{\circ} \mathrm{C}$, a vacuum duration of $15 \mathrm{~min}$, and atmospheric durations of 4 and 2 min [131,132].

A new technique of pulsed vacuum drying combined with carboxymethyl cellulose coating (optimal concentration was $2.0 \% w / w$ ) allowed higher drying efficiency, less drying shrinkage, the preservation of colour, and an improvement of the quality of dried goji berries (total polysaccharides and phenolics) have been proposed as effective pre-treatment dehydration models for goji berries [133]). Carboxymethyl cellulose is a hydrocolloid that can form a flexible and transparent coating on the surface, limiting mass transfer resistance from inside the berry. At the same time, pressure pulsation affects the formation of a porous structure, which facilitates the transfer of mass and heat during drying [133]. Interestingly, Qi et al. (2021) suggest that low-intensity pulsed ultrasound-assisted vacuum drying at $50{ }^{\circ} \mathrm{C}$ with a pulsed ultrasound ratio of 10 s:10s is a novel, promising drying technique for goji berries juice [134].

\subsection{Encapsulation of Bioactive Compounds from Goji Berries}

As previously mentioned, goji berries are a source of numerous bioactive components, such as polysaccharides, carotenoids, and phenolics. These molecules can be isolated from goji berries and further used in the food and pharmaceutical industries. The water-soluble bioactive components of goji berries are traditionally extracted using hot water as a solvent. In order to improve the extraction efficiency, numerous novel extraction methods have been developed, including ultrasound- or microwave-assisted aqueous extractions [135,136], as well as subcritical water extraction [137]. In addition to the extraction method, other factors may affect the extraction procedure, including the origin of fruits, selected solvent, extraction time, and temperature, etc. Several research groups have demonstrated that higher phenolic compounds can be extracted by using ethanol as a solvent rather than water [138]. The efficiency of other solvents for extraction has been studied, including ultrapure water, acetone, ethanol, and methanol in different concentrations and mixtures [139]. Zhou et al. (2020) have demonstrated that the extraction solvents (water, hydrochloric acid $0.4 \%$, or sodium hydroxide $0.6 \%$ solution) used for extraction at different temperatures affect the structures of the extracted polysaccharides. Alkali extractions resulted in low galacturonic acid and higher protein content than acidic and water extractions. In particular, low-temperature alkaline extraction conditions have led to extensively branched rhamnogalacturonan I, whereas high-temperature acidic conditions provided homogalacturonan regions, and resulted in the removal of part of the side chain [140]. Ahmadi et al. (2022) have also reported that the highest galacturonic acid contents were obtained by hot acid extraction [141]. A similar effect was reported on the stability of black goji berry anthocyanins, under variable $\mathrm{pH}$ conditions [57]. Water or acidified solvents are predominantly used for anthocyanin extraction, and they also indicated that the storage stability of the crude black goji anthocyanin extract is high in acidic ( $\mathrm{pH}$ of 3-4) and low in alkaline $\mathrm{pH}$ [57]. Therefore, if water is used as the extraction solvent, it is necessary to carefully investigate the influence of $\mathrm{pH}$ on the stability of the obtained extracts.

The extraction process can be optimised for high(est) yield, bioactivity, and/or resource efficiency, by varying the relevant parameters through an experimental design. The obtained, optimised extracts can be used for further processing. Box-Behnken, as a response surface design, and different factorial designs, have been reported to optimize the goji berries extraction procedures.

Jixian Zhang et al. (2021) reported that the polysaccharides of goji berries stabilized and maintained the morphology of selenium nanoparticles. Moreover, these polysaccharideSeNPs possess structural stability during digestion, and can enhance the absorption and bioavailability of selenium [142]. In addition, the polysaccharides of goji berries in combination with some minerals or other macromolecules can easily lead to gelling, or help form gel network structures $[143,144]$. For example, the addition of $\mathrm{Ca}^{2+}$ ions plays a crucial role in forming the gel network structure in the polysaccharide of goji berries, which enables their 
broader application in the food industry [144]. On the other hand, goji polysaccharides support the formation of gels of heat-induced whey protein at different $\mathrm{pHs}$, and encourage the development of new gel-type foods [143].

Carotenoids from goji berries are lipophilic and unstable molecules, easily degraded under the influence of light, heat, or oxygen. For this reason, they are often extracted from berries and incorporated into appropriate delivery systems, which improve their bioavailability. Till now, different types of oil, such as soybean, sunflower, palm, or cottonseed, have been applied as carriers of carotenoids separated from goji puree [145]. Moreover, the bioaccessibility of carotenoid esters, primarily zeaxanthin esters, is significantly increased when goji berries are mixed with $\mathrm{O} / \mathrm{W}$ emulsion [146]. This also represents a new food model for increasing the bioaccessibility of carotenoids from different fruits. According to recent studies, carotenoid esters extracted or separated from goji berries have been incorporated into nanoemulsion [147], or nanocarriers formed by complex coacervation between gelatin and sodium carboxymethyl cellulose [148]. De Campo et al. (2018) have exploited the use of cactus cladode mucilage (Opuntia monacantha, (Willd.) Haw., Cactaceae) as an encapsulation agent for zeaxanthin. Due to its lipophilic properties, the encapsulation of zeaxanthin by the mucilage polysaccharides may provide improved solubility in water. Furthermore, it has been demonstrated that the encapsulation provided improved stability against various agents [149]. Hempel et al. (2017) have studied the effect of the ripening of goji berries on the conversion of carotenoids from being bound to chloroplastidal thylakoids, to their accumulation in the nano-scale liquid-crystalline state, predominantly in the form of zeaxanthin dipalmitate [79].

Lipid-based nanoparticles were derived from goji berries, specifically from the lipid contents extracted from goji berries [150]. The lipidomic analysis of the obtained nanoparticles was performed, as well as the analysis of the bioactive flavone. Vitexin-2-O-rhamnoside was detected in the lipid nanoparticles. Experiments have indicated the capacity of goji berries' lipid nanoparticles to inhibit the secretion of the main pro-inflammatory cytokines, and to regulate the expression of anti-inflammatory factors. It has further been demonstrated that the obtained nanoparticles can relieve ulcerative colitis symptoms.

Polyphenols from goji berries' leaves have been encapsulated in liposomes to improve their delivery in terms of sustaining their release, and avoiding the burst effect compared to the dissolution of the free extract [151]. The obtained liposomes have successfully served as carriers for polyphenols and demonstrated a cytoprotective effect on L-929 mouse fibroblasts cells.

Finally, the whole aqueous extracts of goji berries encapsulated in maltodextrin can be used as potentially prebiotic food additives, because they have been shown to support growth and viability, and stimulate the proliferation of probiotic strains of bacteria, such as Bifidobacterium and Lactobacillus, in simulated gastrointestinal conditions [152]. The same research group [153] has also demonstrated that the aqueous extracts of goji berries, where the encapsulation was performed with minimal maltodextrin content and high polyphenols content, had high antioxidant and antimicrobial activity. Such products could be used for the preservation of food or plant protection.

\section{Goji Berry as Source of Functional Ingredients in Different Food Products}

Recently, goji berries have become increasingly used as a raw material for the production of specific beverages, or incorporated into various food products, such as bakery, confectionery, meat, and milk products, contributing to their nutritional, health-promoting, and sensory properties (Figure 2) [18,20]. The applications of goji berries as functional ingredients in the formulation of different food products are reviewed and shown in Table 4. 


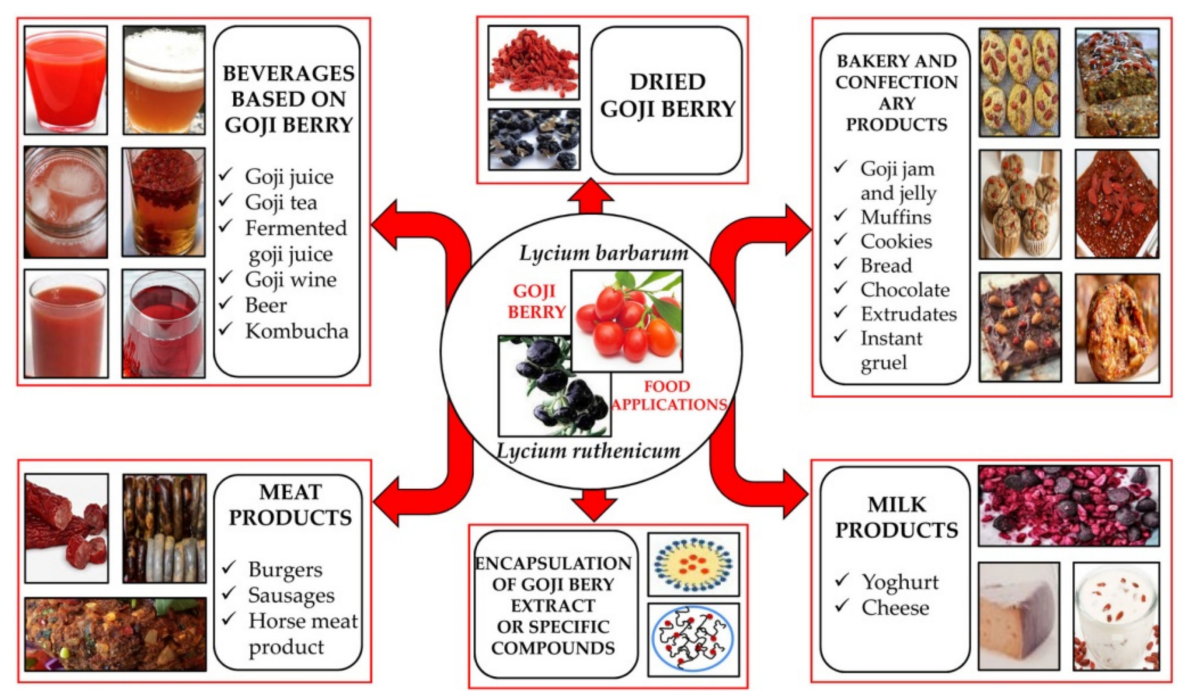

Figure 2. Goji berry-based functional food products.

\subsection{Goji Berry as a Raw Material or a Functional Ingredient in the Production of Beverages}

Goji berries (red and black) were used for goji juice production [102,154], goji tea [70], and specific fermented beverages such as fermented goji juice [155-158], goji wine [159,160], and kombucha beverages [161]. Fermented goji beverages had high TPC, TFC, and TAcy content, as well as good in vitro antioxidant properties evaluated using $\mathrm{DPPH}^{\bullet}, \mathrm{ABTS}^{\bullet+}$, FRAP, CUPRAC, and ORAC assays [155,156,159,161]. More precisely, bioactive compounds such as phenolic acids ( $p$-hydroxybenzoic, $p$-coumaric, and ferulic acid), rutin, and various volatile compounds were predominantly identified in fermented beverages [156,158,162]. In addition, goji juice fermented by probiotics (Lactobacillus and/or Streptococcus sp.) showed high cellular antioxidant activity (HepG2 cells) [155], improved function against ulcerative colitis, decreased intestinal permeability, and modulated gut microbiota [157]. Moreover, fermented goji beverages generally had moderate colour intensity, a specific odour/flavour (fruity, honey, floral and vanilla) related to volatile compounds, balanced taste (slightly sour and sweet), and good acceptability by consumers [156,158,159].

Goji berries were also successfully used as a functional ingredient in different stages of the production of amber ale beer [162]. Beer with goji berries had increased contents of total phenolics, some individually phenolic compounds (rutin, $p$-coumaric, and ferulic acid) and AA-2 $\beta \mathrm{G}$, as well as good antioxidant potential. In addition, these beers had good sensory acceptability with specific sensations of odour and taste, such as red fruit, honey, caramel, coffee, hay, smoke, and a balanced ratio of bitterness and sourness [162]. Finally, black goji extract can be used as a functional ingredient and natural colour in many food products [163]. This extract predominantly contains petunidin derivatives, primarily cis and trans isomers of petunidin-3- $p$-coumaroyl-rutinoside-5-O-glucoside, responsible for colour retention and improvement intensity, and the stability of colour in wide $\mathrm{pH}$ ranges [163].

\subsection{Goji Berries as Functional Ingredients in Meat Products}

Goji extract has been successfully incorporated in products of minced catfish [164] and horse meat $[165,166]$ to improve sensory properties and oxidative stability during storage. Moreover, chitosan/goji extract can be used as a biopreservative and antilisterial agent when mixed with minced catfish [164].

The addition of goji berries or extract in sausages effectively suppressed lipolysis and protein/lipid oxidation, reduced microbial count during storage, and preserved the bright red colour, fresh aroma, and taste of sausages [167,168]. Furthermore, beef burgers with different shares of goji puree $(0 \%, 2.5 \%$, and $5 \%)$ had increased total phenolic content, decreased lipid peroxidation, and good antioxidant properties, as well as a pleasing odour, taste, flavour and texture for various groups of consumers (young, adult, and elderly) [169]. 
Interestingly, the meat of rabbits fed with goji berries as a dietary supplement had increased total phenolic content, decreased oxidation and unchanged colour, water-holding capacity, and muscle tenderness [170,171]. Moreover, meatballs made from the meat of rabbit fed with goji berry had a high sensory score and were more acceptable in terms of colour, juiciness, taste, and overall liking [171].

\subsection{Goji Berries as Functional Ingredients in Confectionery and Bakery Products}

Goji berry sweet products, such as jam or jelly, had good antioxidant potential and high scores for colour, consistency, flavour, and sweetness. However, these products had lower sensory scores for sourness and aftertaste [172]. On the other hand, different confectionery and bakery products can be fortified with various shares of goji berries to improve their functional, sensory, or texture properties. For example, rice extrudates and instant gruels with an increasing share of dry goji berry in mixture had increased content of total phenolics, some individually phenolic acids, rutin, zeaxanthin dipalmitate, and AA-2 $\beta G$, as well as higher antioxidant properties $[173,174]$.

In addition, muffins and cookies enriched with different shares of goji berries powder or by-products had increased total phenolic, insoluble, and soluble fibre contents, and good sensory properties (sourness, slightly sweet and specific flavour). They darkened the colour of the extrudates via the Maillard reaction $[175,176]$. However, muffins and cookies enriched with goji berry by-products had decreased firmness and hardness/fracturability, respectively [175]. Furthermore, gluten-free bread, progressively enriched with goji berries in the range of $0 \%$ to $15 \%$, had decreased bread volume, hardness, lightness of bread crumbs, increased redness, elasticity, and cohesion of bread crumb [177]. The addition of goji berries $(9 \% w / w)$ in prebiotic chocolates has changed the perception of most aroma, flavour, and texture attributes; that is, it increased and improved the bitter taste, bitter aftertaste, astringency, adherence, grittiness, hardness, and aroma of the goji berry [178]. More precisely, chocolate with goji berries had consumer acceptance scores above six on a 9-point scale.

\subsection{Goji Berries as Functional Ingredients in Milk Products}

Incorporating goji berries or extract into milk products such as probiotic yogurt [179-181] and cheese [182] contributes to an increase in the TPC and antioxidant activities of these products. Goji berries also improved the viability of lactic acid bacteria in yoghurt during storage [180]. Furthermore, cheese with goji extracts showed decreased inhibitory activity in the angiotensin-converting enzyme (ACE). However, cheese enriched with goji extract/fish collagen had the highest production of peptides after the 14th and 28th days of storage, which could potentially have anti-ACE activity [182]. Finally, in the study of Rotar et al. (2015), a sensory analysis showed that consumers preferred yogurt with $7 \%$ goji berries, with a score of 8.21 points on the hedonic scale [180]. 
Table 4. An overview in the functional food products development using goji berries or goji berry products.

\begin{tabular}{|c|c|c|c|c|c|c|}
\hline \multirow{2}{*}{ Products } & \multirow{2}{*}{ Goji Berries } & \multirow{2}{*}{$\begin{array}{l}\text { Microbial Species Involved in } \\
\text { Fermentation }\end{array}$} & \multicolumn{2}{|c|}{ Main Observations } & \multirow{2}{*}{ Specific Note } & \multirow{2}{*}{ Reference } \\
\hline & & & Functional Properties & Sensory and Texture Properties & & \\
\hline \multicolumn{7}{|c|}{ BEVERAGES } \\
\hline Kombucha beverages & $\begin{array}{c}\text { Dried goji berries: } \\
\text { 1. Red goji berry } \\
\text { (Lycium barbarum L.) } \\
\text { 2. Black goji berry } \\
\text { (Lycium ruthenicum Murr.) }\end{array}$ & $\begin{array}{l}\text { Kombucha culture: } \\
\text { Symbiosis of acetic acid } \\
\text { bacteria and yeast species }\end{array}$ & $\begin{array}{c}\text { 1. High TPC } \\
\text { 2. High antioxidant } \\
\text { properties (DPPH }{ }^{\bullet}, \text { FRAP } \\
\text { and CUPRAC) }\end{array}$ & $\begin{array}{l}\text { 1. Decrease colour intensity due } \\
\text { to microbial transformation of } \\
\text { phenolics (high score) } \\
\text { 2. Odour highly acceptable(smell } \\
\text { from fruity to acetic acid) } \\
\text { 3. Taste (fruity, sour and } \\
\text { sparkling flavour) }\end{array}$ & $\begin{array}{l}\text { Increased TPC and } \\
\text { antioxidant properties } \\
\left(\text { except DPPH }^{\circ}\right) \text { after } \\
\text { in vitro digestion }\end{array}$ & [161] \\
\hline Fermented goji juice & Goji berries extract & $\begin{array}{c}\text { Lactobacillus plantarum } \\
\text { RV21797 }\end{array}$ & $\begin{array}{l}\text { 1. High TPC, TFC and TAcy } \\
\text { 2. Expressed in vitro } \\
\text { antioxidant properties } \\
\text { (DPPH }{ }^{\bullet}, \text { ABTS }{ }^{+}, \text {FRAP and } \\
\text { ORAC) } \\
\text { 3. High cellular antioxidant } \\
\text { activity (HepG2 Cells) }\end{array}$ & 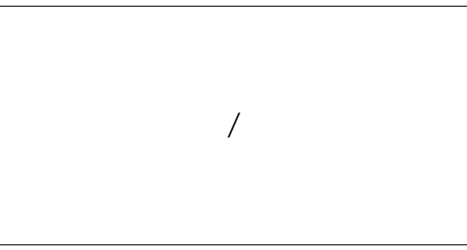 & / & [155] \\
\hline Fermented goji juice & $\begin{array}{l}\text { Dried goji berries } \\
\text { (soaked goji berries) }\end{array}$ & $\begin{array}{l}\text { Bacillus velezensis, Bacillus } \\
\text { licheniformis, Lactobacillus reuteri, } \\
\text { L. rhamnosus and L. plantarum }\end{array}$ & $\begin{array}{l}\text { 1. High TPC and TFC } \\
\text { 2. High } p \text {-hydroxybenzoic } \\
\text { acid, } p \text {-coumaric acid and } \\
\text { rutin content } \\
\text { 3. High individually volatile } \\
\text { compounds content } \\
\text { 4. High antioxidant activity } \\
\text { (DPPH }{ }^{\bullet} \text { and hydroxyl radical) }\end{array}$ & $\begin{array}{l}\text { 1. Colour is moderate, very good } \\
\text { 2. Flavour (aroma of goji juice is } \\
\text { pure and has no odour) } \\
\text { 3. Taste (slightly acidic or sweet) } \\
\text { 4. Acceptability (very like) }\end{array}$ & / & [157] \\
\hline Goji berry tea & $\begin{array}{l}\text { Dried goji berries: } \\
\text { 1. Red goji berry } \\
\text { (Lycium barbarum L.) } \\
\text { 2. Black goji berry } \\
\text { (Lycium ruthenicum) }\end{array}$ & / & $\begin{array}{c}\text { 1. High TPC } \\
\text { 2. High LBP content } \\
\text { 3. High antioxidant activity } \\
\left(\mathrm{DPPH}^{\bullet}, \mathrm{ABTS}^{\bullet+} \text { and FRAP) }\right.\end{array}$ & $\begin{array}{l}\text { 1. Colour of red and black goji } \\
\text { berry tea were light } \\
\text { yellow and purple, respectively, } \\
\text { and then colour gradually } \\
\text { changed to darker with the } \\
\text { increase of time and temperature } \\
\text { of soaking }\end{array}$ & $\begin{array}{l}\text { This study monitored the } \\
\text { effects of various } \\
\text { temperatures and times of } \\
\text { soak on antioxidant } \\
\text { properties of specific goji } \\
\text { berry tea. }\end{array}$ & {$[70]$} \\
\hline
\end{tabular}


Table 4. Cont.

\begin{tabular}{|c|c|c|c|c|c|c|}
\hline \multirow{2}{*}{ Products } & \multirow{2}{*}{ Goji Berries } & \multirow{2}{*}{$\begin{array}{l}\text { Microbial Species Involved in } \\
\text { Fermentation }\end{array}$} & \multicolumn{2}{|c|}{ Main Observations } & \multirow{2}{*}{ Specific Note } & \multirow{2}{*}{ Reference } \\
\hline & & & Functional Properties & Sensory and Texture Properties & & \\
\hline $\begin{array}{l}\text { Fermented goji juice } \\
\text { by probiotics }\end{array}$ & $\begin{array}{l}\text { Dried goji berries } \\
\text { (soaked goji berries) }\end{array}$ & $\begin{array}{l}\text { Lactobacillus plantarum, L. reuteri } \\
\text { and Streptococcus thermophilus }\end{array}$ & $\begin{array}{l}\text { 1. Decreases the levels of } \\
\text { pro-inflammatory cytokines } \\
\text { and total superoxide } \\
\text { dismutase in serum and colon } \\
\text { 2. Increased the levels of } \\
\text { anti-inflammatory cytokines, } \\
\text { myeloperoxidase and } \\
\text { glutathione peroxidase } \\
\text { 3. Decreases intestinal } \\
\text { permeability } \\
\text { 4. Modulate gut microbiota }\end{array}$ & / & $\begin{array}{l}\text { Probiotics fermentation of } \\
\text { goji berry juice } \\
\text { contributing to enhanced } \\
\text { the anti-ulcerative } \\
\text { colitis function. }\end{array}$ & [157] \\
\hline Fermented goji juice & $\begin{array}{l}\text { Fully ripe and frozen goji } \\
\text { berries (goji purre } \\
\text { crashed with pectinase) }\end{array}$ & $\begin{array}{l}\text { Lactiplantibacillus plantarum, } \\
\text { Lactobacillus acidophilus, L. } \\
\text { helveticus, Fructobacillus } \\
\text { fructosus, Weissella cibaria }\end{array}$ & $\begin{array}{l}\text { 1. Highly individually } \\
\text { volatile compounds content } \\
\text { (93 volatile compounds and } \\
\text { seven non-volatile } \\
\text { organic acids) }\end{array}$ & $\begin{array}{l}\text { 1. Juices fermented with L. } \\
\text { plantarum or } \\
\text { L. acidophilus were described with } \\
\text { 'honey', 'wild jujube' odours and } \\
\text { 'sour' taste } \\
\text { 2. Juices with L. helveticus were } \\
\text { described with 'goji berry', 'floral' } \\
\text { and sweetness } \\
\text { 3. Juices with F. fructosus or W. } \\
\text { cibaria were described with } \\
\text { 'vinegar' and sweetness }\end{array}$ & $\begin{array}{l}\text { L. helveticus } 6024 \text { is the } \\
\text { most active strain able to } \\
\text { retain or liberated the key } \\
\text { compounds positively } \\
\text { associated with 'goji } \\
\text { berry' note. }\end{array}$ & [158] \\
\hline $\begin{array}{l}\text { Goji juice and } \\
\text { goji capsules }\end{array}$ & Goji berries & / & $\begin{array}{l}\text { 1. Source of nutritional and } \\
\text { mineral elements }\end{array}$ & / & $\begin{array}{l}\text { Goji capsules contained } \\
\text { higher concentration of } \\
\text { all individually minerals } \\
\text { compared to } \\
\text { goji juice samples. }\end{array}$ & [154] \\
\hline Goji wine & $\begin{array}{l}\text { Dried goji berries } \\
\quad \text { (goji puree) }\end{array}$ & Saccharomyces cerevisiae & $\begin{array}{l}\text { 1. High TPC and TFC } \\
\text { 2. High LBPs content } \\
\text { 3. High individually volatile } \\
\text { compounds content } \\
\text { 4. High antioxidant activity } \\
\left(\text { DPPH }^{\bullet} \text { and } \text { ABTS }^{\bullet+}\right)\end{array}$ & $\begin{array}{l}\text { 1. Flavour (woody, vanillia and } \\
\text { clove aroma), aroma related with } \\
\text { compounds such as cis- and } \\
\text { trans-whisky lactone, vanillin, } \\
\text { eugenol, isoeugenol, and } \\
\text { 4-vinylguaiacol } \\
\text { 2. The highest score in olfactory } \\
\text { and gustative attributes }\end{array}$ & $\begin{array}{l}\text { This study monitored the } \\
\text { effects of various oak } \\
\text { matrices (medium toast } \\
\text { barrel, medium toast } \\
\text { shavings, non-toast chips, } \\
\text { light toast chips, medium } \\
\text { toast chips, and heavy } \\
\text { toast chips) on the } \\
\text { volatiles and antioxidant } \\
\text { activity in Goji wine. } \\
\text { Thus, Goji wine treated } \\
\text { with oak shavings had the } \\
\text { highest antioxidant } \\
\text { activity, phenolics and } \\
\text { flavonoids content }\end{array}$ & [159] \\
\hline
\end{tabular}


Table 4. Cont.

\begin{tabular}{|c|c|c|c|c|c|c|}
\hline \multirow{2}{*}{ Products } & \multirow{2}{*}{ Goji Berries } & \multirow{2}{*}{$\begin{array}{l}\text { Microbial Species Involved in } \\
\text { Fermentation }\end{array}$} & \multicolumn{2}{|c|}{ Main Observations } & \multirow{2}{*}{ Specific Note } & \multirow{2}{*}{ Reference } \\
\hline & & & Functional Properties & Sensory and Texture Properties & & \\
\hline Goji berry juice & Dehydrated goji berries & / & $\begin{array}{l}\text { 1. High protocatehuic acid, } \\
\text { vanillic acid, } p \text {-coumaric acid, } \\
\text { catechin and rutin content } \\
\text { 2. Goji juice caused toxicity } \\
\text { and reduced the lifespan of } \\
\text { Caenorhabditis elegans } \\
\text { 3. Goji juice increased } \\
\text { lipofuscin, glucose levels, } \\
\text { number of apoptotic bodies } \\
\text { and lipase activity }\end{array}$ & / & $\begin{array}{l}\text { High concentration of goji } \\
\text { juice showed toxic effects } \\
\text { and promoted premature } \\
\text { aging in C. elegans. Thus, } \\
\text { goji juice should be } \\
\text { carefully consumed until } \\
\text { further studies } \\
\text { are conducted. }\end{array}$ & [102] \\
\hline $\begin{array}{l}\text { Black goji extract as } \\
\text { source of natural colour }\end{array}$ & Dried black goji berries & / & $\begin{array}{l}\text { 1. High content of petunidin } \\
\text { derivatives, primarily cis and } \\
\text { trans isomers of } \\
\text { petunidin-3- } p \text {-coumaroyl- } \\
\text { rutinoside-5-O-glucoside }\end{array}$ & $\begin{array}{l}\text { Acylated petunidin anthocyanins } \\
\text { are responsible for colour } \\
\text { retention and improvement of } \\
\text { colour intensity and stability. }\end{array}$ & $\begin{array}{l}\text { Black goji anthocyanins } \\
\text { produced various colour } \\
\text { shades in broad ranges } \\
\text { of } \mathrm{pH} .\end{array}$ & [163] \\
\hline Goji wine & $\begin{array}{l}\text { Dried goji berries (mixed } \\
\text { with water and } \\
\text { decomposed } \\
\text { with pectolase) }\end{array}$ & Saccharomyces cerevisiae & / & / & $\begin{array}{l}\text { Ethyl carbamate was } \\
\text { formed during the } \\
\text { fermentation and storage } \\
\text { processes of goji wine. }\end{array}$ & [160] \\
\hline \multicolumn{7}{|c|}{ MEAT PRODUCTS } \\
\hline Minced catfish & Goji berry extract & / & / & $\begin{array}{l}\text { High score for odour, texture, } \\
\text { colour and overall quality of } \\
\text { catfish minced blended with } \\
\text { chitosan/goji berry extract, } \\
\text { immediately after mixing and } \\
\text { after } 14 \text { days of storage. }\end{array}$ & $\begin{array}{l}\text { Chitosan/goji berry } \\
\text { extract can be used as a } \\
\text { biopreservative and } \\
\text { anti-listerial agents } \\
\text { (prevents the growth of } \\
\text { Listeria monocytogenes), } \\
\text { and also enhanced } \\
\text { sensory properties and } \\
\text { storage stability, when is } \\
\text { mixed with } \\
\text { catfish minced. }\end{array}$ & [164] \\
\hline Beef burgers & $\begin{array}{c}\text { Goji puree } \\
(0 \% ; 2.5 \% \text {; and } 5 \%)\end{array}$ & / & $\begin{array}{l}\text { Burgers with goji: } \\
\text { 1. Increased TPC } \\
\text { 2. Improved antioxidant } \\
\text { properties (DPPH }{ }^{\bullet}, \text { ABTS } \\
\text { and ORAC) } \\
\text { 3. Decreased lipid } \\
\text { peroxidation }\end{array}$ & $\begin{array}{l}\text { Burgers had acceptable } \\
\text { appearance, odour, taste, flavour } \\
\text { and texture for all groups of } \\
\text { consumers (young, adult } \\
\text { and elderly) }\end{array}$ & $\begin{array}{l}\text { Burgers with goji had } \\
\text { significantly higher TPC } \\
\text { and antioxidant } \\
\text { properties after } \\
\text { in vitro digestion }\end{array}$ & [169] \\
\hline
\end{tabular}


Table 4. Cont.

\begin{tabular}{|c|c|c|c|c|c|c|}
\hline \multirow{2}{*}{ Products } & \multirow{2}{*}{ Goji Berries } & \multirow{2}{*}{$\begin{array}{c}\text { Microbial Species Involved in } \\
\text { Fermentation }\end{array}$} & \multicolumn{2}{|c|}{ Main Observations } & \multirow{2}{*}{ Specific Note } & \multirow{2}{*}{ Reference } \\
\hline & & & Functional Properties & Sensory and Texture Properties & & \\
\hline Cooked sausages & $\begin{array}{l}\text { Dried goji berries } \\
(0.5 \% \text { and } 1 \%)\end{array}$ & / & / & $\begin{array}{l}\text { The addition of } 0.5 \% \text { goji berries } \\
\text { had the highest contribution to } \\
\text { the preservation of bright red } \\
\text { colour, fresh aroma and taste of } \\
\text { functional cooked sausages }\end{array}$ & $\begin{array}{l}\text { The addition of } 0.5 \% \text { and } \\
1 \% \text { of goji berries } \\
\text { effectively inhibited } \\
\text { protein oxidation, } \\
\text { lipolysis, and lipid } \\
\text { oxidation in functional } \\
\text { cooked sausages }\end{array}$ & [167] \\
\hline Rabbit meat & $\begin{array}{l}\text { Rabbit feed was } \\
\text { supplemented with 3\% } \\
\text { goji berries }\end{array}$ & / & / & $\begin{array}{l}\text { Consumers gave a higher score } \\
\text { for meatballs produced of meat of } \\
\text { rabbits which were fed with goji } \\
\text { berries dietary supplementation. } \\
\text { These samples had more } \\
\text { acceptable colour, juiciness, taste } \\
\text { and overall liking. }\end{array}$ & $\begin{array}{l}\text { Meat obtained of rabbits } \\
\text { fed with goji berries } \\
\text { dietary supplementation } \\
\text { had reduced TBARS } \\
\text { values and significant } \\
\text { impact on Lactobacillus } \\
\text { spp. prevalence. }\end{array}$ & [170] \\
\hline $\begin{array}{l}\text { Smoked common carp } \\
\text { sausages }\end{array}$ & $\begin{array}{l}\text { Goji berry extracts } \\
(1 \% \text { and } 2 \%)\end{array}$ & / & / & $\begin{array}{l}\text { 1. Sausages with goji berry } \\
\text { extract had partial redness colour } \\
2 \text {. The highest score of aroma and } \\
\text { colour had sausages with } \\
1 \% \text { goji extract. }\end{array}$ & $\begin{array}{l}\text { Sausages supplemented } \\
\text { with goji extracts had } \\
\text { decreased TBA values, } \\
\text { TVB-N contents and total } \\
\text { aerobic mesophilic } \\
\text { bacteria during storage, } \\
\text { in comparison to control } \\
\text { sample (without goji). }\end{array}$ & [168] \\
\hline $\begin{array}{l}\text { Cooked and smoked } \\
\text { horse meat product }\end{array}$ & $\begin{array}{l}\text { Goji berry extract and goji } \\
\text { berry extract/buckwheat } \\
\text { flour }\end{array}$ & / & / & $\begin{array}{l}\text { A high score for appearance, } \\
\text { shear, colour, taste, odour and } \\
\text { consistency were evaluated for a } \\
\text { horsemeat product enriched with } \\
\text { goji extract or } \\
\text { goji/buckwheat mixture. }\end{array}$ & / & [165] \\
\hline Rabbit meat & $\begin{array}{l}\text { Rabbit feed was } \\
\text { supplemented with 1\% } \\
\text { and 3\% goji berries }\end{array}$ & / & $\begin{array}{l}\text { Meat obtained of rabbits fed } \\
\text { with goji berries dietary } \\
\text { supplementation: } \\
\text { 1. Increased TPC } \\
\text { 2. Improved antioxidant } \\
\text { properties (ORAC) }\end{array}$ & $\begin{array}{c}\text { Goji berries dietary } \\
\text { supplementation did not affect } \\
\text { the colour, water holding capacity } \\
\text { and tenderness of rabbit } \\
\text { meat muscle. }\end{array}$ & $\begin{array}{l}\text { Meat obtained of rabbits } \\
\text { which were fed with } 3 \% \\
\text { goji berries dietary } \\
\text { supplementation showed } \\
\text { an increase in } \\
\text { oxidative stability. }\end{array}$ & [171] \\
\hline $\begin{array}{l}\text { Kazakh horse-meat } \\
\text { product }\end{array}$ & $\begin{array}{l}\text { Goji berry extract } \\
(0.5 \% \text { and } 1 \%)\end{array}$ & / & & $\begin{array}{l}\text { A high score for surface colour, } \\
\text { smell and taste were evaluated } \\
\text { for a horsemeat product enriched } \\
\text { with } 0.5 \% \text { and } 1 \% \text { goji extract. }\end{array}$ & $\begin{array}{l}\text { Horse meat products with } \\
1.0 \% \text { of goji extract had } \\
\text { improved oxidative } \\
\text { stability. On the other } \\
\text { hand, adding of goji } \\
\text { berries had destructive } \\
\text { effect on most meat fiber. }\end{array}$ & [166] \\
\hline
\end{tabular}


Table 4. Cont.

\begin{tabular}{|c|c|c|c|c|c|c|}
\hline \multirow{2}{*}{ Products } & \multirow{2}{*}{ Goji Berries } & \multirow{2}{*}{$\begin{array}{c}\text { Microbial Species Involved in } \\
\text { Fermentation }\end{array}$} & \multicolumn{2}{|c|}{ Main Observations } & \multirow{2}{*}{ Specific Note } & \multirow{2}{*}{ Reference } \\
\hline & & & Functional Properties & Sensory and Texture Properties & & \\
\hline \multicolumn{7}{|c|}{ BAKERY AND CONFECTIONERY PRODUCTS } \\
\hline Goji jam and jelly & Dehydrated goji berries & / & $\begin{array}{l}\text { 1. High antioxidant activity } \\
\left(\mathrm{DPPH}^{\bullet}\right)\end{array}$ & $\begin{array}{l}\text { Both goji products had high score } \\
\text { for colour, appearance, consistency, } \\
\text { flavour and sweet taste, however, } \\
\text { for sour taste and aftertaste } \\
\text { products had lower scores. }\end{array}$ & / & [172] \\
\hline $\begin{array}{l}\text { Muffins and spritz } \\
\text { cookies }\end{array}$ & $\begin{array}{l}\text { Whole goji berries } \\
\text { (0\% and } 10 \%) \\
\text { Goji powder } \\
(0 \%, 3 \%, 5 \% \text { and } 10 \%)\end{array}$ & / & / & $\begin{array}{l}\text { 1. Pastry products with goji } \\
\text { berries had a sour, slightly sweet } \\
\text { and specific flavour. } \\
\text { 2. Consumer's preferred muffins } \\
\text { with } 10 \% \text { whole goji and cookies } \\
\text { with } 5 \% \text { goji powder. }\end{array}$ & / & [176] \\
\hline Muffins and cookies & $\begin{array}{c}\text { Goji berry by-products } \\
(0 \%, 10 \%, 20 \%, 30 \% \\
\text { and } 40 \%)\end{array}$ & / & $\begin{array}{l}\text { Bakery products enriched } \\
\text { with goji by-products: } \\
\text { 1. Increased TPC } \\
\text { 2. Increased insoluble and } \\
\text { soluble fibre }\end{array}$ & $\begin{array}{l}\text { 1. Increased goji by-products } \\
\text { level decreased muffin firmness, } \\
\text { that is, hardness and } \\
\text { fracturability of cookies. } \\
2 . \text { Muffins with } 20 \% \text { of goji } \\
\text { by-products and cookies with } \\
10 \% \text { of goji by-products had the } \\
\text { best sensory properties. }\end{array}$ & / & [175] \\
\hline $\begin{array}{l}\text { Prebiotic white } \\
\text { chocolate }\end{array}$ & $\begin{array}{l}\text { Dried goji berries } \\
\quad(9 \% w / w)\end{array}$ & / & / & $\begin{array}{l}\text { 1. According to quantitative } \\
\text { descriptive analysis, adding goji } \\
\text { berries in chocolate reduced the } \\
\text { perception of most aroma and } \\
\text { flavour attributes, and improved } \\
\text { the bitter taste, bitter aftertaste, } \\
\text { astringency, and most of the } \\
\text { texture attributes } \\
\text { 2. Increased adherence, grittiness, } \\
\text { hardness, astringency and goji } \\
\text { berry aroma in comparison with } \\
\text { control sample. } \\
\text { 3. Chocolates enriched with goji } \\
\text { berries had acceptance scores } \\
\text { above } 6 \text { on a 9-point scale. }\end{array}$ & / & [178] \\
\hline
\end{tabular}


Table 4. Cont.

\begin{tabular}{|c|c|c|c|c|c|c|}
\hline \multirow{2}{*}{ Products } & \multirow{2}{*}{ Goji Berries } & \multirow{2}{*}{$\begin{array}{c}\text { Microbial Species Involved in } \\
\text { Fermentation }\end{array}$} & \multicolumn{2}{|c|}{ Main Observations } & \multirow{2}{*}{ Specific Note } & \multirow{2}{*}{ Reference } \\
\hline & & & Functional Properties & Sensory and Texture Properties & & \\
\hline $\begin{array}{l}\text { Rice flour based } \\
\text { extrudates }\end{array}$ & $\begin{array}{c}\text { Dry goji berries } \\
(0 \%, 13 \%, 23 \% \text { and } 28.5 \%)\end{array}$ & / & $\begin{array}{l}\text { Increasing goji berry level in } \\
\text { rice flour based extrudates } \\
\text { resulted in: } \\
\text { 1. Increased TPC } \\
\text { 2. Increased antioxidant } \\
\text { activity (DPPH }{ }^{\bullet} \text { and ABTS } \\
\text { 3. Increased rutin, zeaxanthin } \\
\text { dipalmitate and AA-2 } \beta G \\
\text { content (content of listed } \\
\text { compounds were higher in } \\
\text { samples before extrusion) }\end{array}$ & 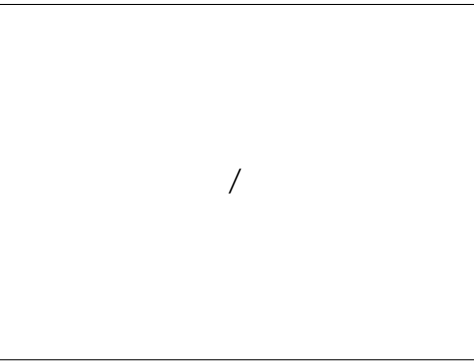 & / & [173] \\
\hline Instant gruels & $\begin{array}{l}\text { Dry goji berries } \\
(1 \%, 3 \% \text { and } 5 \%)\end{array}$ & / & $\begin{array}{l}\text { Increasing goji berry level in } \\
\text { instant corn gruels resulted in: } \\
\text { 1. Increased TPC } \\
\text { 2. Increased antioxidant } \\
\text { activity (TEAC and } \\
\text { TLC-DPPH }{ }^{\bullet} \text { ) } \\
\text { 3. Increased protocatehuic, } \\
\text { 4-OH-benzoic, } p \text {-coumaric, } \\
\text { ferulic, isoferulic and salicylic } \\
\text { acid content }\end{array}$ & / & $\begin{array}{l}\text { This study also monitored } \\
\text { time (10 and } 15 \mathrm{~min}) \text { and } \\
\text { rotation speed of the } \\
\text { extruder screw }(80 \mathrm{rpm}, \\
100 \mathrm{rpm} \text { and } 120 \mathrm{rpm})\end{array}$ & [174] \\
\hline
\end{tabular}


Table 4. Cont.

\begin{tabular}{|c|c|c|c|c|c|c|}
\hline \multirow{2}{*}{ Products } & \multirow{2}{*}{ Goji Berries } & \multirow{2}{*}{$\begin{array}{l}\text { Microbial Species Involved in } \\
\text { Fermentation }\end{array}$} & \multicolumn{2}{|c|}{ Main Observations } & \multirow{2}{*}{ Specific Note } & \multirow{2}{*}{ Reference } \\
\hline & & & Functional Properties & Sensory and Texture Properties & & \\
\hline \multicolumn{7}{|c|}{ MILK PRODUCTS } \\
\hline Yoghurt & $\begin{array}{c}\text { Dried goji berries } \\
\text { (aqueous/ethanolic } \\
\text { extract) } \\
(0.05 \%, 0.1 \% \text { and } \\
0.15 \% w / v)\end{array}$ & $\begin{array}{l}\text { Commercial yoghurt culture } \\
\text { (yo-FAST-88), Hansen, } \\
\text { Denmark }\end{array}$ & $\begin{array}{c}\text { Increasing goji extract level in } \\
\text { yoghurt resulted in: } \\
\text { 1. Increased TPC } \\
\text { 2. Increased antioxidant } \\
\text { activity (DPPH }{ }^{\bullet} \text { ) }\end{array}$ & $\begin{array}{l}\text { Increasing goji extract level in } \\
\text { yogurt decreased consumer } \\
\text { acceptability, with the same trend } \\
\text { at the 1st day and after } 20 \text { days. }\end{array}$ & / & [179] \\
\hline Yoghurt & $\begin{array}{c}\text { Goji berries with/without } \\
\text { honey } \\
(0 \%, 3 \%, 5 \% \text { and } 7 \%)\end{array}$ & $\begin{array}{c}\text { Starter mezophylic culture } \\
\text { Lyofast Y450B } \\
\text { (Streptococcus thermophilus and } \\
\text { Lactobacillus delbrueckii subsp. } \\
\text { bulgaricus (ratio 1:1)) }\end{array}$ & 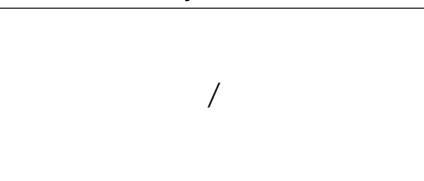 & $\begin{array}{l}\text { Consumers preferred } \\
\text { yoghurt with } 7 \% \text { goji berries } \\
\text { (8.21 points on hedonic scale) }\end{array}$ & $\begin{array}{l}\text { Goji berries maintained } \\
\text { viability of lactic acid } \\
\text { bacteria in yoghurt during } \\
\text { storage }\end{array}$ & [180] \\
\hline Yoghurt & $\begin{array}{l}\text { Dry and ground goji } \\
\text { berries } \\
(2 \%, 4 \% \text { and } 6 \%)\end{array}$ & $\begin{array}{c}\text { Lactobacillus delbreukii ssp. } \\
\text { bulgaricus, Streptococcus } \\
\text { thermophilus }\end{array}$ & $\begin{array}{l}\text { Increasing goji extract level in } \\
\text { yoghurt resulted in: } \\
\text { 1. Increased TPC } \\
\text { 2. Increased antioxidant } \\
\left.\text { activity (DPPH }{ }^{\circ}\right)\end{array}$ & / & $\begin{array}{l}\text { Total phenolic content } \\
\text { and antioxidant activity } \\
\text { of yogurt enriched with } \\
\text { goji berries is } \\
\text { continuously reduced } \\
\text { after 3th, 7th and 14th } \\
\text { days of storage. }\end{array}$ & [181] \\
\hline Cheese & $\begin{array}{l}\text { 1. Dried goji berries ( } 3 \% \\
\text { water extract) } \\
\text { 2. Goji extract/fish } \\
\text { collagen }\end{array}$ & Lactic acid bacteria & $\begin{array}{l}\text { 1. Cheese with goji extract } \\
\text { showed decreased ACE } \\
\text { inhibitory activity } \\
\text { 2. Cheese enriched with goji } \\
\text { extract and fish collagen had } \\
\text { the most enhanced peptides } \\
\text { production after 14th and } \\
\text { 28th days of storage, and } \\
\text { potential anti-ACE activity. }\end{array}$ & / & / & [182] \\
\hline
\end{tabular}




\section{Conclusions and Future Directions}

Increasing scientific evidence on the health-promoting effects of goji berries has increased interest in the possible application of goji berries or their extracts as raw materials or functional additives in various food products. Several important conclusions regarding goji berries valorisation in the functional food industry can be drawn from previous research studies: (1) Goji berries are sensitive and easily susceptible to spoilage, which requires new postharvest and storage investigation to prolong the stability of fresh goji berries; (2) Dried goji berries can be found most often in the market, but in the future, more attention should be focused on applying modern drying technologies with appropriate pre-treatments to produce dried goji berries with better nutritional value and sensory properties; (3) Goji berry products or products fortified with goji berry have improved nutritional, functional, and sensory properties; (4) Sensory and texture properties generally depend on the share of goji berry added in the final products; (5) Consumption of highly concentrated goji products such as juice can potentially have an adverse effect and require additional research in the future; (6) New micro- and nanoencapsulation models should be investigated in the future, to protect sensitive compounds from goji berries during processing, and ensure their better absorption during digestion; (7) Further research should also examine the effect of the food matrix on the phenolic profile and the functional properties of incorporated goji berries; (8) During the processing of goji berries, significant quantities of their by-products are formed. Thus, in the future, attention should be paid to the valorisation of goji by-products and their application in the food industry; (9) It has been shown that goji berries' addition to feeding improves rabbit meat quality; this should also be confirmed with other animals.

Finally, the efficacy and safety of goji berry-based food products and nutraceuticals need to be proven through well-designed clinical trials. Moreover, the possible interactions of goji berry with conventional medications and natural health products need investigation in more detail.

Author Contributions: Conceptualization, B.B.V. and M.B.P.; writing—original draft preparation, B.B.V., D.D.M., M.D.M., J.D.D., T.D.I. and A.Ž.K.; writing—review and editing, B.B.V., D.D.M., M.D.M., and M.B.P.; visualization, D.D.M.; supervision, M.B.P.; project administration, B.B.V., and M.B.P.; funding acquisition, B.B.V. All authors have read and agreed to the published version of the manuscript.

Funding: This work was supported by the Ministry of Education, Science and Technological Development, Republic of Serbia through grant numbers 451-03-9/2021-14/200161 and 451-03-9/2021-14/200116.

Institutional Review Board Statement: Not applicable.

Informed Consent Statement: Not applicable.

Data Availability Statement: Data are contained within the article.

Conflicts of Interest: The authors declare no conflict of interest.

\section{References}

1. De Souza, V.R.; Pereira, P.A.P.; da Silva, T.L.T.; de Oliveira Lima, L.C.; Pio, R.; Queiroz, F. Determination of the bioactive compounds, antioxidant activity and chemical composition of Brazilian blackberry, red raspberry, strawberry, blueberry and sweet cherry fruits. Food Chem. 2014, 156, 362-368. [CrossRef] [PubMed]

2. Mikulic-Petkovsek, M.; Schmitzer, V.; Slatnar, A.; Stampar, F.; Veberic, R. Composition of sugars, organic acids, and total Phenolics in 25 wild or cultivated berry species. J. Food Sci. 2012, 77, C1064-C1070. [CrossRef] [PubMed]

3. Golovinskaia, O.; Wang, C.K. Review of functional and pharmacological activities of berries. Molecules 2021, 26, 3904. [CrossRef] [PubMed]

4. Salo, H.M.; Nguyen, N.; Alakärppä, E.; Klavins, L.; Hykkerud, A.L.; Karppinen, K.; Jaakola, L.; Klavins, M.; Häggman, H. Authentication of berries and berry-based food products. Compr. Rev. Food Sci. Food Saf. 2021, 20, 5197-5225. [CrossRef] [PubMed]

5. Chang, S.K.; Alasalvar, C.; Shahidi, F. Superfruits: Phytochemicals, antioxidant efficacies, and health effects-A comprehensive review. Crit. Rev. Food Sci. Nutr. 2019, 59, 1580-1604. [CrossRef] [PubMed]

6. Lasekan, O. Exotic berries as a functional food. Curr. Opin. Clin. Nutr. Metab. Care. 2014, 17, 589-595. [CrossRef]

7. Yao, R.; Heinrich, M.; Weckerle, C.S. The genus Lycium as food and medicine: A botanical, ethnobotanical and historical review. J. Ethnopharmacol. 2018, 212, 50-66. [CrossRef] 
8. Donno, D.; Beccaro, G.L.; Mellano, M.G.; Cerutti, A.K.; Bounous, G. Goji berry fruit (Lycium spp.): Antioxidant compound fingerprint and bioactivity evaluation. J. Funct. Foods 2015, 18, 1070-1085. [CrossRef]

9. Potterat, O. Goji (Lycium barbarum and L. chinense): Phytochemistry, pharmacology and safety in the perspective of traditional uses and recent popularity. Planta Med. 2010, 76, 7-19. [CrossRef]

10. Yao, R.; Heinrich, M.; Zou, Y.; Reich, E.; Zhang, X.; Chen, Y.; Weckerle, C.S. Quality variation of goji (fruits of Lycium spp.) in China: A comparative morphological and metabolomic analysis. Front. Pharmacol. 2018, 9, 151. [CrossRef]

11. Yao, R.; Heinrich, M.; Zhao, X.; Wang, Q.; Wei, J.; Xiao, P.G. What's the choice for goji: Lycium barbarum L. or L. chinense Mill? J. Ethnopharmacol. 2021, 276, 114185. [CrossRef] [PubMed]

12. Amagase, H.; Farnsworth, N.R. A review of botanical characteristics, phytochemistry, clinical relevance in efficacy and safety of Lycium barbarum fruit (Goji). Food Res. Int. 2011, 44, 1702-1717. [CrossRef]

13. Pedro, A.C.; Sánchez-Mata, M.-C.; Pérez-Rodríguez, M.L.; Cámara, M.; López-Colón, J.L.; Bach, F.; Bellettini, M.; Haminiuk, C.W.I. Qualitative and nutritional comparison of goji berry fruits produced in organic and conventional systems. Sci. Hortic. 2019, 257, 108660. [CrossRef]

14. Niro, S.; Fratianni, A.; Panfili, G.; Falasca, L.; Cinquanta, L.; Alam, M.R. Nutritional evaluation of fresh and dried goji berries cultivated in Italy. Ital. J. Food Sci. 2017, 29, 398-408.

15. Benchennouf, A.; Grigorakis, S.; Loupassaki, S.; Kokkalou, E. Phytochemical analysis and antioxidant activity of Lycium barbarum (Goji) cultivated in Greece. Pharm. Biol. 2017, 55, 596-602. [CrossRef]

16. Mocan, A.; Moldovan, C.; Zengin, G.; Bender, O.; Locatelli, M.; Simirgiotis, M.; Atalay, A.; Vodnar, D.C.; Rohn, S.; Crișan, G. UHPLC-QTOF-MS analysis of bioactive constituents from two Romanian Goji (Lycium barbarum L.) berries cultivars and their antioxidant, enzyme inhibitory, and real-time cytotoxicological evaluation. Food Chem. Toxicol. 2018, 115, 414-424. [CrossRef]

17. Ruffo, M.; Parisi, O.I.; Amone, F.; Malivindi, R.; Gorgoglione, D.; De Biasio, F.; Scrivano, L.; Pezzi, V.; Puoci, F. Calabrian Goji vs. Chinese Goji: A comparative study on biological properties. Foods 2017, 6, 30. [CrossRef]

18. Jiang, Y.; Fang, Z.; Leonard, W.; Zhang, P. Phenolic compounds in Lycium berry: Composition, health benefits and industrial applications. J. Funct. Foods 2021, 77, 104340. [CrossRef]

19. Povolo, C.; Foschini, A.; Ribaudo, G. Optimization of the extraction of bioactive molecules from Lycium barbarum fruits and evaluation of the antioxidant activity: A combined study. Nat. Prod. Res. 2019, 33, 2694-2698. [CrossRef]

20. Pires, T.C.S.P.; Dias, M.I.; Barros, L.; Calhelha, R.C.; Alves, M.J.; Santos-Buelga, C.; Ferreira, I.C.F.R. Phenolic compounds profile, nutritional compounds and bioactive properties of Lycium barbarum L.: A comparative study with stems and fruits. Ind. Crops Prod. 2018, 122, 574-581. [CrossRef]

21. Kafkaletou, M.; Christopoulos, M.V.; Tsaniklidis, G.; Papadakis, I.; Ioannou, D.; Tzoutzoukou, C.; Tsantili, E. Nutritional value and consumer-perceived quality of fresh goji berries (Lycium barbarum L. and L. chinense L.) from plants cultivated in Southern Europe. Fruits 2018, 73, 5-12. [CrossRef]

22. Skenderidis, P.; Kerasioti, E.; Karkanta, E.; Stagos, D.; Kouretas, D.; Petrotos, K.; Hadjichristodoulou, C.; Tsakalof, A. Assessment of the antioxidant and antimutagenic activity of extracts from goji berry of Greek cultivation. Toxicol. Rep. 2018, 5, $251-257$. [CrossRef] [PubMed]

23. Dzhugalov, H.; Lichev, V.; Yordanov, A.; Kaymakanov, P.; Dimitrova, V.; Kutoranov, G. First results of testing Goji berry (Lycium barbarum L.) in Plovdiv region, Bulgaria. Sci. Pap. Ser. B Hortic. 2015, LIX, 47-50.

24. Vulić, J.J.; Čanadanović-Brunet, J.M.; Ćetković, G.S.; Djilas, S.M.; Tumbas Šaponjac, V.T.; Stajčić, S.S. Bioactive compounds and antioxidant properties of goji fruits (Lycium barbarum L.) cultivated in Serbia. J. Am. Coll. Nutr. 2016, 35, 692-698. [CrossRef]

25. Ilić, T.; Dodevska, M.; Marčetić, M.; Božić, D.; Kodranov, I.; Vidović, B. Chemical characterization, antioxidant and antimicrobial properties of goji berries cultivated in Serbia. Foods 2020, 9, 1614. [CrossRef] [PubMed]

26. Covaci, E.; Senilă, M.; Leopold, L.F.; Olah, N.K.; Cobzac, C.; Petropulos, V.I.; Balabanova, B.; Cadar, O.; Becze, A.; Ponta, M.; et al. Characterization of Lycium barbarum L. berry cultivated in North Macedonia: A chemometric approach. J. Berry Res. 2020, 10, 223-241. [CrossRef]

27. Kosinska-Cagnazzo, A.; Weber, B.; Chablais, R.; Vouillamoz, J.F.; Molnár, B.; Crovadore, J.; Lefort, F.; Andlauer, W. Bioactive compound profile and antioxidant activity of fruits from six goji cultivars cultivated in Switzerland. J. Berry Res. 2017, 7, 43-59. [CrossRef]

28. Wojdyło, A.; Nowicka, P.; Bąbelewski, P. Phenolic and carotenoid profile of new goji cultivars and their anti-hyperglycemic, anti-aging and antioxidant properties. J. Funct. Foods 2018, 48, 632-642. [CrossRef]

29. Kulaitienè, J.; Vaitkevičienè, N.; Jarienè, E.; Černiauskienė, J.; Jeznach, M.; Paulauskienè, A. Concentrations of minerals, soluble solids, vitamin C, carotenoids and toxigenic elements in organic goji berries (Lycium barbarum L.) cultivated in Lithuania. Biol. Agric. Hortic. 2020, 36, 130-140. [CrossRef]

30. Lopatriello, A.; Previtera, R.; Pace, S.; Werner, M.; Rubino, L.; Werz, O.; Taglialatela-Scafati, O.; Forino, M. NMR-based identification of the major bioactive molecules from an Italian cultivar of Lycium barbarum. Phytochemistry 2017, $144,52-57$. [CrossRef]

31. Carnés, J.; de Larramendi, C.H.; López-Matas, M.A.; Ferrer, A.; Huertas, J. Allergenic sensitisation mediated by Wolfberry. In Lycium barbarum and Human Health, 1st ed.; Chang, R.C.-C., So, K.-F., Eds.; Springer: Dordrecht, The Netherlands; Berlin/Heidelberg, Germany; New York, NY, USA, 2015; pp. 179-198. 
32. Uasuf, C.G.; De Angelis, E.; Guagnano, R.; Pilolli, R.; D’Anna, C.; Villalta, D.; Brusca, I.; Monaci, L. Emerging allergens in goji berry superfruit: The identification of new IgE binding proteins towards allergic patients' sera. Biomolecules 2020, 10, 689. [CrossRef] [PubMed]

33. Montesano, D.; Rocchetti, G.; Cossignani, L.; Lucini, L.; Simonetti, M.S.; Blasi, F. Italian Lycium barbarum L. berry: Chemical characterization and nutraceutical value. Nat. Prod. Commun. 2018, 13, 1151-1156. [CrossRef]

34. Zhao, D.; Li, S.; Han, X.; Li, C.; Ni, Y.; Hao, J. Physico-chemical properties and free amino acids profiles of six wolfberry cultivars in Zhongning. J. Food Compos. Anal. 2020, 88, 103460. [CrossRef]

35. Bertoldi, D.; Cossignani, L.; Blasi, F.; Perini, M.; Barbero, A.; Pianezze, S.; Montesano, D. Characterisation and geographical traceability of Italian goji berries. Food Chem. 2019, 275, 585-593. [CrossRef] [PubMed]

36. Wojcieszek, J.; Kwiatkowski, P.; Ruzik, L. Speciation analysis and bioaccessibility evaluation of trace elements in goji berries (Lycium barbarum L.). J. Chromatogr. A 2017, 1492, 70-78. [CrossRef]

37. Cossignani, L.; Blasi, F.; Simonetti, M.S.; Montesano, D. Fatty acids and phytosterols to discriminate geographic origin of Lycium barbarum berry. Food. Anal. Methods 2017, 11, 1180-1188. [CrossRef]

38. Lu, Y.; Guo, S.; Zhang, F.; Yan, H.; Qian, D.W.; Shang, E.X.; Wang, H.Q.; Duan, J.A. Nutritional components characterization of goji berries from different regions in China. J. Pharm. Biomed. Anal. 2021, 195, 113859. [CrossRef]

39. Jiang, H.; Zhang, W.; Li, X.; Xu, Y.; Cao, J.; Jiang, W. The anti-obesogenic effects of dietary berry fruits: A review. Food Res. Int. 2021, 147, 110539. [CrossRef]

40. Zhu, W.; Zhou, S.; Liu, J.; McLean, R.J.C.; Chu, W. Prebiotic, immuno-stimulating and gut microbiota-modulating effects of Lycium barbarum polysaccharide. Biomed. Pharmacother. 2020, 121, 109591. [CrossRef]

41. Ma, Z.F.; Zhang, H.; Teh, S.S.; Wang, C.W.; Zhang, Y.; Hayford, F.; Wang, L.; Ma, T.; Dong, Z.; Zhang, Y.; et al. Goji berries as a potential natural antioxidant medicine: An insight into their molecular mechanisms of action. Oxid. Med. Cell. Longev. 2019, $2019,2437397$. [CrossRef]

42. Qian, D.; Zhao, Y.; Yang, G.; Huang, L. Systematic review of chemical constituents in the genus Lycium (Solanaceae). Molecules 2017, 22, 911. [CrossRef] [PubMed]

43. Jin, M.; Huang, Q.; Zhao, K.; Shang, P. Biological activities and potential health benefit effects of polysaccharides isolated from Lycium barbarum L. Int. J. Biol. Macromol. 2013, 54, 16-23. [CrossRef] [PubMed]

44. Redgwell, R.J.; Curti, D.; Wang, J.; Dobruchowska, J.M.; Gerwig, G.J.; Kamerling, J.P.; Bucheli, P. Cell wall polysaccharides of Chinese Wolfberry (Lycium barbarum): Part 1. Characterisation of soluble and insoluble polymer fractions. Carbohydr. Polym. 2011, 84, 1344-1349. [CrossRef]

45. Wu, D.; Guo, H.; Lin, S.; Lam, S.C.; Zhao, L.; Lin, D.; Qin, W. Review of the structural characterization, quality evaluation, and industrial application of Lycium barbarum polysaccharides. Trends Food Sci. Technol. 2018, 79, 171-183. [CrossRef]

46. Xie, J.; Wu, D.T.; Li, W.Z.; Ning, C.G.; Tang, Y.P.; Zhao, J.; Li, S.P. Effects of polysaccharides in Lycium barbarum berries from different regions of China on macrophages function and their correlation to the glycosidic linkages. J. Food Sci. 2017, 82, 2411-2420. [CrossRef]

47. Wang, Y.; Jin, H.; Dong, X.; Yang, S.; Ma, S.; Ni, J. Quality evaluation of Lycium barbarum (wolfberry) from different regions in China based on polysaccharide structure, yield and bioactivities. Chin. Med. 2019, 14, 49. [CrossRef]

48. Masci, A.; Carradori, S.; Casadei, M.A.; Paolicelli, P.; Petralito, S.; Ragno, R.; Cesa, S. Lycium barbarum polysaccharides: Extraction, purification, structural characterisation and evidence about hypoglycaemic and hypolipidaemic effects. A review. Food Chem. 2018, 254, 377-389. [CrossRef]

49. Wu, D.T.; Cheong, K.L.; Deng, Y.; Lin, P.C.; Wei, F.; Lv, X.J.; Long, Z.R.; Zhao, J.; Ma, S.C.; Li, S.P. Characterization and comparison of polysaccharides from Lycium barbarum in China using saccharide mapping based on PACE and HPTLC. Carbohydr. Polym. 2015, 134, 12-19. [CrossRef]

50. Zhang, M.; Wang, J.; Zhang, S. Study on the composition of Lycium barbarum polysaccharides and its effects on the growth of weanling mice. Wei Sheng Yan Jiu 2002, 31, 118-119.

51. Zhou, Z.Q.; Xiao, J.; Fan, H.X.; Yu, Y.; He, R.R.; Feng, X.L.; Kurihara, H.; So, K.F.; Yao, X.S.; Gao, H. Polyphenols from wolfberry and their bioactivities. Food Chem. 2017, 214, 644-654. [CrossRef]

52. Shah, T.; Bule, M.; Niaz, K. Goji Berry (Lycium barbarum)—A superfood. In Nonvitamin and Nonmineral Nutritional Supplements; Nabavi, S.M., Silva, A.S., Eds.; Academic Press: Cambridge, MA, USA, 2019; pp. 257-264.

53. Chen, S.; Zhou, H.; Zhang, G.; Meng, J.; Deng, K.; Zhou, W.; Wang, H.; Wang, Z.; Hu, N.; Suo, Y. Anthocyanins from Lycium ruthenicum Murr. ameliorated D-galactose-induced memory impairment, oxidative stress, and neuroinflammation in adult rats. $J$. Agric. Food Chem. 2019, 67, 3140-3149. [CrossRef] [PubMed]

54. Zhang, G.; Chen, S.; Zhou, W.; Meng, J.; Deng, K.; Zhou, H.; Hu, N.; Suo, Y. Anthocyanin composition of fruit extracts from Lycium ruthenicum and their protective effect for gouty arthritis. Ind. Crop. Prod. 2019, 129, 414-423. [CrossRef]

55. Luo, Y.; Fang, J.L.; Yuan, K.; Jin, S.H.; Guo, Y. Ameliorative effect of purified anthocyanin from Lycium ruthenicum on atherosclerosis in rats through synergistic modulation of the gut microbiota and NF-кB/SREBP-2 pathways. J. Funct. Foods 2019, 59, 223-233. [CrossRef]

56. Yin, J.J.; Wu, T. Anthocyanins from black wolfberry (Lycium ruthenicum Murr.) prevent inflammation and increase fecal fatty acid in diet-induced obese rats. RSC Adv. 2017, 7, 47848-47853. [CrossRef] 
57. Gamage, G.C.V.; Lim, Y.Y.; Choo, W.S. Black goji berry anthocyanins: Extraction, stability, health benefits, and applications. ACS Agric. Sci. Technol. 2021, 8, 1360-1370.

58. Nimalaratne, C.; Lopes-Lutz, D.; Schieber, A.; Wu, J. Effect of domestic cooking methods on egg yolk xanthophylls. J. Agric. Food Chem. 2012, 60, 12547-12552. [CrossRef]

59. Toyoda-Ono, Y.; Maeda, M.; Nakao, M.; Yoshimura, M.; Sugiura-Tomimori, N.; Fukami, H. 2-O-(beta-D-glucopyranosyl) ascorbic acid, a novel ascorbic acid analogue isolated from Lycium fruit. J. Agric. Food Chem. 2004, 52, 2092-2096. [CrossRef]

60. Zhang, Q.; Chen, W.; Zhao, J.; Xi, W. Functional constituents and antioxidant activities of eight Chinese native goji genotypes. Food Chem. 2016, 200, 230-236. [CrossRef]

61. Skenderidis, P.; Lampakis, D.; Giavasis, I.; Leontopoulos, S.; Petrotos, K.; Hadjichristodoulou, C.; Tsakalof, A. Chemical properties, fatty-acid composition, and antioxidant activity of goji berry (Lycium barbarum L. and Lycium chinense Mill.) fruits. Antioxidants 2019, 8, 60. [CrossRef]

62. Zhou, Y.; Qu, H.; Zhu, H.; Wang, Y.; Jiang, Y. Postharvest Handling of Fresh Goji Berries in Phytochemicals in Goji Berries, 1st ed.; CRC Press: Boca Raton, FL, USA, 2020.

63. Islam, T.; Yu, X.; Singh Badwai, T.; Xu, B. Comparative studies on phenolic profiles, antioxidant capacities and carotenoid contents of red goji berry (Lycium barbarum) and black goji berry (Lycium ruthenicum). Chem. Cent. J. 2017, 11, 59. [CrossRef]

64. Yossa Nzeuwa, I.B.; Guo, B.; Zhang, T.; Wang, L.; Ji, Q.; Xia, H.; Sun, G. Comparative metabolic profiling of Lycium fruits (Lycium barbarum and Lycium chinense) from different areas in China and from Nepal. J. Food Qual. 2019, 2019, 4396027. [CrossRef]

65. Ozkan, E.E.; Ozden, T.Y.; Toplan, G.G.; Mat, A. Phenolic content and biological activities of Lycium barbarum L (Solanaceae) fruits (Goji berries) cultivated in Konya, Turkey. Trop. J. Pharm. Res. 2018, 17, 2047-2053. [CrossRef]

66. Xin, G.; Zhu, F.; Du, B.; Xu, B. Antioxidants distribution in pulp and seeds of black and red goji berries as affected by boiling processing. J. Food Qual. 2017, 2017, 3145946. [CrossRef]

67. Zhao, W.; Shi, Y. Comprehensive analysis of phenolic compounds in four varieties berries at different ripening stages by UPLC-MS/MS. J. Food Compost. Anal. 2021, 106, 104279. [CrossRef]

68. Lu, Y.; Kong, X.; Zhang, J.; Guo, C.; Qu, Z.; Jin, L.; Wang, H. Composition changes in Lycium ruthenicum fruit dried by different methods. Front. Nutr. 2021, 8, 737521. [CrossRef]

69. Wu, T.; Lv, H.; Wang, F.; Wang, Y. Characterization of polyphenols from Lycium ruthenicum fruit by UPLC-Q-TOF/MSE and their antioxidant activity in Caco 2 cells. J. Agric. Food Chem. 2016, 64, 2280-2288. [CrossRef]

70. Liu, B.; Xu, Q.; Sun, Y. Black goji berry (Lycium ruthenicum) tea has higher phytochemical contents and in vitro antioxidant properties than red goji berry (Lycium barbarum) tea. Food Qual. Saf. 2020, 4, 193-201. [CrossRef]

71. Kulczyński, B.; Gramza-Michałowska, A. Goji berry (Lycium barbarum): Composition and health effects-A review. Pol. J. Food Nutr. Sci. 2016, 66, 67-75. [CrossRef]

72. Niki, E.; Noguchi, N. Evaluation of antioxidant capacity. What capacity is being measured by which method? IUBMB Life 2000, 50, 323-329. [CrossRef]

73. Lin, C.L.; Wang, C.C.; Chang, S.C.; Inbaraj, B.S.; Chen, B.H. Antioxidative activity of polysaccharide fractions isolated from Lycium barbarum Linnaeus. Int. J. Biol. Macromol. 2009, 45, 146-151. [CrossRef]

74. Wang, C.C.; Chang, S.C.; Inbaraj, B.S.; Chen, B.H. Isolation of carotenoids, flavonoids and polysaccharides from Lycium barbarum L. and evaluation of antioxidant activity. Food Chem. 2010, 120, 184-192. [CrossRef]

75. Asker, M.M.S.; Mahmoud, M.G.; Ibrahim, G.S. Structural characterization and biological activity of acidic polysaccharide fractions isolated from Bacillus polymyxa NRC-A. Res. J. Appl. Sci. 2007, 3, 1170-1177.

76. Bucheli, P.; Gao, Q.; Redgwell, R.; Karine, V.; Wang, J.; Zhang, W.; Nong, S.; Cao, B. Biomolecular and Clinical Aspects of Chinese Wolfberry. In Herbal Medicine: Biomolecular and Clinical Aspects, 2nd ed.; Benzie, I., Wachtel, G.S., Eds.; CRC Press: Boca Raton, FL, USA, 2011; pp. 289-314.

77. Zhang, Z.; Liu, X.; Zhang, X.; Liu, J.; Hao, Y.; Yang, X.; Wang, Y. Comparative evaluation of the antioxidant effects of the natural vitamin $C$ analog 2-O-beta-D-glucopyranosyl-L-ascorbic acid isolated from goji berry fruit. Arch. Pharm Res. 2011, 34, 801-810. [CrossRef] [PubMed]

78. Liu, Z.; Liu, B.; Wen, H.; Tao, Y.; Shao, Y. Phytochemical profiles, nutritional constituents and activity of black wolfberry (Lycium ruthenicum Murr.). Ind. Crops Prod. 2020, 154, 112692. [CrossRef]

79. Hempel, J.; Schädle, C.N.; Sprenger, J.; Heller, A.; Carle, R.; Schweiggert, R.M. Ultrastructural deposition forms and bioaccessibility of carotenoids and carotenoid esters from goji berries (Lycium barbarum L.). Food Chem. 2017, 218, 525-533. [CrossRef]

80. Trevithick-Sutton, C.C.; Foote, C.S.; Collins, M.; Trevithick, J.R. The retinal carotenoids zeaxanthin and lutein scavenge superoxide and hydroxyl radicals: A chemiluminescence and ESR study. Mol. Vis. 2006, 12, 1127-1135. [PubMed]

81. Cheng, C.Y.; Chung, W.Y.; Szeto, Y.T.; Benzie, I.F. Fasting plasma zeaxanthin response to Fructus barbarum L. (wolfberry; Kei Tze) in a food-based human supplementation trial. Br. J. Nutr. 2005, 93, 123-130. [CrossRef]

82. Amagase, H.; Nance, D.M. A randomized, double-blind, placebo-controlled, clinical study of the general effects of a standardized Lycium barbarum (Goji) juice, GoChi. J. Altern Complement. Med. 2008, 14, 403-412. [CrossRef]

83. Amagase, H.; Sun, B.; Borek, C. Lycium barbarum (goji) juice improves in vivo antioxidant biomarkers in serum of healthy adults. Nutr. Res. 2009, 29, 19-25. [CrossRef]

84. Yu, D.H.; Wu, J.M.; Niu, A.J. Health-promoting effect of LBP and healthy Qigong exercise on physiological functions in old subjects. Carbohydr. Polym. 2009, 75, 312-316. [CrossRef] 
85. Amagase, H.; Sun, B.; Nance, D.M. Immunomodulatory effects of a standardized Lycium barbarum fruit juice in Chinese older healthy human subjects. J. Med. Food. 2009, 12, 1159-1165. [CrossRef] [PubMed]

86. Amagase, H.; Nance, D.M. Lycium barbarum increases caloric expenditure and decreases waist circumference in healthy overweight men and women: Pilot study. J. Am. Coll. Nutr. 2011, 30, 304-309. [CrossRef] [PubMed]

87. Bucheli, P.; Vidal, K.; Shen, L.; Gu, Z.; Zhang, C.; Miller, L.E.; Wang, J. Goji berry effects on macular characteristics and plasma antioxidant levels. Optom. Vis. Sci. 2011, 88, 257-262. [CrossRef] [PubMed]

88. Vidal, K.; Bucheli, P.; Gao, Q.; Moulin, J.; Shen, L.S.; Wang, J.; Blum, S.; Benyacoub, J. Immunomodulatory effects of dietary supplementation with a milk-based wolfberry formulation in healthy elderly: A randomized, double-blind, placebo-controlled trial. Rejuvenation Res. 2012, 15, 89-97. [CrossRef]

89. Cai, H.; Liu, F.; Zuo, P.; Huang, G.; Song, Z.; Wang, T.; Lu, H.; Guo, F.; Han, C.; Sun, G. Practical application of antidiabetic efficacy of Lycium barbarum polysaccharide in patients with type 2 diabetes. Med. Chem. 2015, 11, 383-390. [CrossRef] [PubMed]

90. Lee, Y.J.; Ahn, Y.; Kwon, O.; Lee, M.Y.; Lee, C.H.; Lee, S.; Park, T.; Kwon, S.W.; Kim, J.Y. Dietary wolfberry extract modifies oxidative stress by controlling the expression of inflammatory mRNAs in overweight and hypercholesterolemic subjects: A randomized, double-blind, placebo-controlled trial. J. Agric. Food Chem. 2017, 65, 309-316. [CrossRef]

91. De Souza Zanchet, M.Z.; Nardi, G.M.; de Oliveira Souza Bratti, L.; Filippin-Monteiro, F.B.; Locatelli, C. Lycium barbarum reduces abdominal fat and improves lipid profile and antioxidant status in patients with metabolic syndrome. Oxid. Med. Cell Longev. 2017, 2017, 9763210. [CrossRef]

92. Chan, H.H.; Lam, H.I.; Choi, K.Y.; Li, S.Z.; Lakshmanan, Y.; Yu, W.Y.; Chang, R.C.; Lai, J.S.; So, K.F. Delay of cone degeneration in retinitis pigmentosa using a 12-month treatment with Lycium barbarum supplement. J. Ethnopharmacol. 2019, 236, 336-344. [CrossRef]

93. Van den Driessche, J.J.; Plat, J.; Plasqui, G.; Mensink, R.P. A single dose of goji berries does not affect postprandial energy expenditure and substrate oxidation in healthy, overweight men. J. Nutr. Metab. 2019, 2019, 4057143. [CrossRef]

94. Toh, D.W.K.; Xia, X.; Sutanto, C.N.; Low, J.H.M.; Poh, K.K.; Wang, J.W.; Foo, R.S.; Kim, J.E. Enhancing the cardiovascular protective effects of a healthy dietary pattern with wolfberry (Lycium barbarum): A randomized controlled trial. Am. J. Clin. Nutr. 2021, 114, 80-89. [CrossRef]

95. Toh, D.; Lee, W.Y.; Zhou, H.; Sutanto, C.N.; Lee, D.; Tan, D.; Kim, J.E. Wolfberry (Lycium barbarum) consumption with a healthy dietary pattern lowers oxidative stress in middle-aged and older adults: A randomized controlled trial. Antioxidants 2021, 10, 567. [CrossRef] [PubMed]

96. Li, X.; Holt, R.R.; Keen, C.L.; Morse, L.S.; Yiu, G.; Hackman, R.M. Goji berry intake increases macular pigment optical density in healthy adults: A randomized pilot trial. Nutrients 2021, 13, 4409. [CrossRef] [PubMed]

97. Guo, X.F.; Li, Z.H.; Cai, H.; Li, D. The effects of Lycium barbarum L. (L. barbarum) on cardiometabolic risk factors: A meta-analysis of randomized controlled trials. Food Funct. 2017, 8, 1741-1748. [CrossRef] [PubMed]

98. Benzie, I.F.; Chung, W.Y.; Wang, J.; Richelle, M.; Bucheli, P. Enhanced bioavailability of zeaxanthin in a milk-based formulation of wolfberry (Gou Qi Zi; Fructus barbarum L.). Br. J. Nutr. 2006, 96, 154-160. [CrossRef]

99. Neelam, K.; Dey, S.; Sim, R.; Lee, J.; Au Eong, K.G. Fructus lycii: A natural dietary supplement for amelioration of retinal diseases. Nutrients 2021, 13, 246. [CrossRef]

100. Toh, D.W.K.; Low, J.H.M.; Kim, J.E. Cardiovascular disease risk reduction with wolfberry consumption: A systematic review and meta-analysis of randomized controlled trials. Eur. J. Nutr. 2021. [CrossRef]

101. Amagase, H. General toxicity and histological analysis from acute toxicological study of a standardized Lycium barbarum (Goji) juice (GoChiTM) in rodents. FASEB J. 2008, 22, 722. [CrossRef]

102. De Freitas Rodrigues, C.; Ramos Boldori, J.; Valandro Soares, M.; Somacal, S.; Emanuelli, T.; Izaguirry, A.; Weber Santos Cibin, F.; Rossini Augusti, P.; Casagrande Denardin, C. Goji berry (Lycium barbarum L.) juice reduces lifespan and premature aging of Caenorhabditis elegans: Is it safe to consume it? Food Res. Int. 2021, 144, 110297. [CrossRef]

103. Arroyo-Martinez, Q.; Sáenz, M.J.; Argüelles Arias, F.; Acosta, M.S. Lycium barbarum: A new hepatotoxic "natural" agent? Dig. Liver Dis. 2011, 43, 749. [CrossRef]

104. Karaman, K.; Yılmaz, Y.D.; Özlüer, Y.E.; Çanakçı, S.E.; Deniz, A.T. A new hepatotoxic agent: Goji berry. J. Emerg. Med. Case Rep. 2019, 10, 105-107.

105. Jeszka-Skowron, M.; Zgoła-Grześkowiak, A.; Stanisz, E.; Waśkiewicz, A. Potential health benefits and quality of dried fruits: Goji fruits, cranberries and raisins. Food Chem. 2017, 221, 228-236. [CrossRef] [PubMed]

106. Zhang, Y.; Qin, J.; Wang, Y.; Zhou, T.; Feng, N.; Ma, C.; Zhu, M. Levels and health risk assessment of pesticides and metals in Lycium barbarum L. from different sources in Ningxia, China. Sci. Rep. 2022, 12, 561. [CrossRef] [PubMed]

107. Qin, X.; Luo, X.; Han, J.; Chen, Y.; Zhang, K.; Hu, D. Residual determination of pyrethrins in Lycium barbarum (goji) by GC-MS/MS and a dietary risk assessment of Chinese goji consumption. Food Addit. Contam. Part A 2020, 37, 478-487. [CrossRef] [PubMed]

108. Gómez-Bernal, S.; Rodríguez-Pazos, L.; Martínez, F.J.; Ginarte, M.; Rodríguez-Granados, M.T.; Toribio, J. Systemic photosensitivity due to Goji berries. Photodermatol. Photoimmunol. Photomed. 2011, 27, 245-247. [CrossRef]

109. Larramendi, C.H.; García-Abujeta, J.L.; Vicario, S.; García-Endrino, A.; López-Matas, M.A.; García-Sedeño, M.D.; Carnés, J. Goji berries (Lycium barbarum): Risk of allergic reactions in individuals with food allergy. J. Investig. Allergol. Clin. Immunol. 2012, 22, 345-350. 
110. Monzón Ballarín, S.; López-Matas, M.A.; Sáenz Abad, D.; Pérez-Cinto, N.; Carnés, J. Anaphylaxis associated with the ingestion of Goji berries (Lycium barbarum). J. Investig. Allergol. Clin. Immunol. 2011, 21, 567-570.

111. Zauli, D.; Mirarchi, M.G. Anaphylaxis induced by Goji berries. Ann. Allergy Asthma Immunol. 2015, 114, 535-536. [CrossRef]

112. Carnés, J.; de Larramendi, C.H.; Ferrer, A.; Huertas, A.J.; López-Matas, M.A.; Pagán, J.A.; Navarro, L.A.; García-Abujeta, J.L.; Vicario, S.; Peña, M. Recently introduced foods as new allergenic sources: Sensitisation to Goji berries (Lycium barbarum). Food Chem. 2013, 137, 130-135. [CrossRef]

113. Zhang, J.; Tian, L.; Xie, B. Bleeding due to a probable interaction between warfarin and Gouqizi (Lycium Barbarum L.). Toxicol. Rep. 2015, 2, 1209-1212. [CrossRef]

114. Guzmán, C.E.; Guzmán-Moreno, C.G.; Assad-Morell, J.L.; Carrizales-Sepúlveda, E.F. Flecainide toxicity associated with the use of goji berries: A case report. Eur. Heart J. Case Rep. 2021, 5, ytab204. [CrossRef]

115. Adiletta, G.; Alam, M.; Cinquanta, L.; Russo, P.; Albanese, D.; Matteo, M. Effect of abrasive pretreatment on hot dried goji berry. Chem. Eng. Trans. 2015, 44, 127-132.

116. Deng, L.Z.; Mujumdar, A.S.; Zhang, Q.; Yang, X.H.; Wang, J.; Zheng, Z.A.; Gao, Z.J.; Xiao, H.W. Chemical and physical pretreatments of fruits and vegetables: Effects on drying characteristics and quality attributes-A comprehensive review. Crit. Rev. Food Sci. Nutr. 2019, 59, 1408-1432. [CrossRef] [PubMed]

117. Fratianni, A.; Niro, S.; Alam, M.; Cinquanta, L.; Matteo, M.; Adiletta, G.; Panfili, G. Effect of a physical pre-treatment and drying on carotenoids of goji berries (Lycium barbarum L.). LWT 2018, 92, 318-323. [CrossRef]

118. Ni, J.; Ding, C.; Zhang, Y.; Song, Z. Impact of different pretreatment methods on drying characteristics and microstructure of goji berry under electrohydrodynamic (EHD) drying process. Innov. Food Sci. Emerg. Technol. 2020, 61, 102318. [CrossRef]

119. Russo, P.; Adiletta, G.; Matteo, M.; Senadeera, W.; Cinquanta, L. The effect of abrasive pre-treatment on the drying kinetics and phenolic compounds in goji berries (Lycium barbarum L.). J. Food Process. Preserv. 2020, 44, e14933. [CrossRef]

120. Zhao, D.; Wei, J.; Hao, J.; Han, X.; Ding, S.; Yang, L.; Zhang, Z. Effect of sodium carbonate solution pretreatment on drying kinetics, antioxidant capacity changes, and final quality of wolfberry (Lycium barbarum) during drying. LWT 2018, 99, 254-261. [CrossRef]

121. Song, H.; Bi, J.; Chen, Q.; Zhou, M.; Wu, X.; Song, J. Structural and health functionality of dried goji berries as affected by coupled dewaxing pre-treatment and hybrid drying methods. Int. J. Food Prop. 2018, 21, 2527-2538. [CrossRef]

122. Dermesonlouoglou, E.; Chalkia, A.; Dimopoulos, G.; Taoukis, P. Combined effect of pulsed electric field and osmotic dehydration pre-treatments on mass transfer and quality of air dried goji berry. Innov. Food Sci. Emerg. Technol. 2018, 49, 106-115. [CrossRef]

123. Dermesonlouoglou, E.; Chalkia, A.; Taoukis, P. Application of osmotic dehydration to improve the quality of dried goji berry. J. Food Eng. 2018, 232, 36-43. [CrossRef]

124. Donno, D.; Mellano, M.G.; Raimondo, E.; Cerutti, A.K.; Prgomet, Z.; Beccaro, G.L. Influence of applied drying methods on phytochemical composition in fresh and dried goji fruits by HPLC fingerprint. Eur. Food Res. Technol. 2016, 242, 1961-1974. [CrossRef]

125. Rodrigues Sá, R.; da Cruz Caldas, J.; de Andrade Santana, D.; Vieira Lopes, M.; dos Santos, W.N.L.; Graças Andrade Korn, M.; de Freitas Santos Júnior, A. Multielementar/centesimal composition and determination of bioactive phenolics in dried fruits and capsules containing Goji berries (Lycium barbarum L.). Food Chem. 2019, 273, 15-23. [CrossRef] [PubMed]

126. Zhu, Z.; Luo, W.; Sun, D.W. Effects of liquid nitrogen quick freezing on polyphenol oxidase and peroxide activities, cell water states and epidermal microstructure of wolfberry. LWT 2020, 120, 108923. [CrossRef]

127. Donno, D.; Mellano, M.G.; Riondato, I.; Biaggi, M.; Andriamaniraka, H.; Gamba, G.; Beccaro, G. Traditional and unconventional dried fruit snacks as a source of health-promoting compounds. Antioxidants 2019, 8, 396. [CrossRef] [PubMed]

128. Rybicka, I.; Kiewlicz, J.; Kowalczewski, P.Ł.; Gliszczyńska-Świgło, A. Selected dried fruits as a source of nutrients. Eur. Food Res. Technol. 2021, 247, 2409-2419. [CrossRef]

129. Zhou, Y.H.; Vidyarthi, S.K.; Zhong, C.S.; Zheng, Z.A.; An, Y.; Wang, J.; Wei, Q.; Xiao, H.-W. Cold plasma enhances drying and colour, rehydration ratio and polyphenols of wolfberry via microstructure and ultrastructure alteration. LWT 2020, 134, 110173 [CrossRef]

130. Huang, D.; Yang, P.; Tang, X.; Luo, L.; Sunden, B. Application of infrared radiation in the drying of food products. Trends Food Sci. Technol. 2021, 110, 765-777. [CrossRef]

131. Xie, L.; Mujumdar, A.S.; Fang, X.-M.; Wang, J.; Dai, J.-W.; Du, Z.-L.; Xiao, H.-W.; Liu, Y.; Gao, Z.-J. Far-infrared radiation heating assisted pulsed vacuum drying (FIR-PVD) of wolfberry (Lycium barbarum L.): Effects on drying kinetics and quality attributes. Food Bioprod. Process. 2017, 102, 320-331. [CrossRef]

132. Zhang, W.-P.; Chen, C.; Pan, Z.; Xiao, H.-W.; Xie, L.; Gao, Z.-J.; Zheng, Z.-A. Design and performance evaluation of a pilot-scale pulsed vacuum infrared drying (PVID) system for drying of berries. Dry. Technol. 2020, 38, 1340-1355. [CrossRef]

133. Yu, F.; Li, Y.; Wu, Z.; Wan, N.; Yang, M. Dehydration of wolfberry fruit using pulsed vacuum drying combined with carboxymethyl cellulose coating pretreatment. LWT 2020, 134, 110159. [CrossRef]

134. Qi, Y.; Yu, F.; Wang, X.; Wan, N.; Yang, M.; Wu, Z.; Li, Y. Drying of wolfberry fruit juice using low-intensity pulsed ultrasound. LWT 2021, 141, 110953. [CrossRef]

135. Skenderidis, P.; Petrotos, K.; Giavasis, I.; Hadjichristodoulou, C.; Tsakalof, A. Optimization of ultrasound assisted extraction of of goji berry (Lycium barbarum) fruits and evaluation of extracts' bioactivity. J. Food Process. Eng. 2017, 40, 12522. [CrossRef] 
136. Vilkhu, K.; Mawson, R.; Simons, L.; Bates, D. Applications and opportunities for ultrasound assisted extraction in the food industry-A review. Innov. Food Sci. Emerg. Technol. 2008, 9, 161-169. [CrossRef]

137. Zhang, J.; Wen, C.; Zhang, H.; Duan, Y.; Ma, H. Recent advances in the extraction of bioactive compounds with subcritical water: A review. Trends Food Sci. Technol. 2020, 95, 183-195. [CrossRef]

138. De Moura, C.; dos Reis, A.S.; da Silva, L.D.; de Lima, V.A.; Oldoni, T.L.C.; Pereira, C.; Carpes, S.T. Optimization of phenolic compounds extraction with antioxidant activity from açaí, blueberry and goji berry using response surface methodology. Emir. J. Food Agric. 2018, 30, 180-189.

139. Pedro, A.C.; Maurer, J.B.B.; Zawadzki-Baggio, S.F.; Ávila, S.; Maciel, G.M.; Haminiuk, C.W.I. Bioactive compounds of organic goji berry (Lycium barbarum L.) prevent oxidative deterioration of soybean oil. Ind. Crops Prod. 2018, 112, 90-97. [CrossRef]

140. Zhou, S.; Rahman, A.; Li, J.; Wei, C.; Chen, J.; Linhardt, R.J.; Ye, X.; Chen, S. Extraction methods affect the structure of Goji (Lycium barbarum) polysaccharides. Molecules 2020, 25, 936. [CrossRef]

141. Ahmadi, S.; Yu, C.; Zaeim, D.; Wu, D.; Hu, X.; Ye, X.; Chen, S. Increasing RG-I content and lipase inhibitory activity of pectic polysaccharides extracted from goji berry and raspberry by high-pressure processing. Food Hydrocolloid. 2021, 126, 107477. [CrossRef]

142. Zhang, J.; Yang, X.; Ji, T.; Wen, C.; Ye, Z.; Liu, X.; Liang, L.; Liu, G.; Xu, X. Digestion and absorption properties of Lycium barbarum polysaccharides stabilized selenium nanoparticles. Food Chem. 2022, 373, 131637. [CrossRef]

143. He, Z.; Ma, T.; Zhang, W.; Su, E.; Cao, F.; Huang, M.; Wang, Y. Heat-induced gel formation by whey protein isolate-Lycium barbarum polysaccharides at varying pHs. Food Hydrocoll. 2021, 115, 106607. [CrossRef]

144. Wang, H.; Ke, L.; Ding, Y.; Rao, P.; Xu, T.; Han, H.; Zhou, J.; Ding, W.; Shang, X. Effect of calcium ions on rheological properties and structure of Lycium barbarum L. polysaccharide and its gelation mechanism. Food Hydrocoll. 2022, 122, 107079. [CrossRef]

145. Liu, Y.; Zhang, C.; Cui, B.; Wang, M.; Fu, H.; Wang, Y. Carotenoid-enriched oil preparation and stability analysis during storage: Influence of oils chain length and fatty acid saturation. LWT 2021, 151, 112163. [CrossRef]

146. Kan, X.; Yan, Y.; Ran, L.; Lu, L.; Mi, J.; Zhang, Z.; Li, X.; Zeng, X.; Cao, Y. Evaluation of bioaccessibility of zeaxanthin dipalmitate from the fruits of Lycium barbarum in oil-in-water emulsions. Food Hydrocoll. 2020, 105, 105781. [CrossRef]

147. Luo, Y.; Liu, Y.; Guo, H.; Fu, H. Evaluation of the bioaccessibility of carotenoid esters from Lycium barbarum L. in nano-emulsions: A kinetic approach. Food Res. Int. 2020, 136, 109611. [CrossRef] [PubMed]

148. Zhang, J.; Jia, G.; Wanbin, Z.; Minghao, J.; Wei, Y.; Hao, J.; Liu, X.; Gan, Z.; Sun, A. Nanoencapsulation of zeaxanthin extracted from Lycium barbarum L. by complex coacervation with gelatin and CMC. Food Hydrocoll. 2021, 112, 106280. [CrossRef]

149. De Campo, C.; Dick, M.; dos Santos, P.P.; Costa, T.M.H.; Paese, K.; Guterres, S.S.; de Oliveira Rios, A.; Flores, S.H. Zeaxanthin nanoencapsulation with Opuntia monacantha mucilage as structuring material: Characterization and stability evaluation under different temperatures. Coll. Surf. A Physicochem. Eng. 2018, 558, 410-421. [CrossRef]

150. Zu, M.; Song, H.; Zhang, J.; Chen, Q.; Deng, S.; Canup, B.S.; Yuan, Y.; Xiao, B. Lycium barbarum lipid-based edible nanoparticles protect against experimental colitis. Coll. Surf. B 2020, 187, 110747. [CrossRef] [PubMed]

151. Păvăloiu, R.D.; Sha'at, F.; Neagu, G.; Deaconu, M.; Bubueanu, C.; Albulescu, A.; Sha'at, M.; Hlevca, C. Encapsulation of polyphenols from Lycium barbarum leaves into liposomes as a strategy to improve their delivery. Nanomaterials 2021, 11, 1938. [CrossRef] [PubMed]

152. Skenderidis, P.; Mitsagga, C.; Lampakis, D.; Petrotos, K.; Giavasis, I. The Effect of Encapsulated Powder of Goji Berry (Lycium barbarum) on Growth and Survival of Probiotic Bacteria. Microorganisms 2019, 8, 57. [CrossRef]

153. Skenderidis, P.; Mitsagga, C.; Giavasis, I.; Petrotos, K.; Lampakis, D.; Leontopoulos, S.; Hadjichristodoulou, C.; Tsakalof, A. The in vitro antimicrobial activity assessment of ultrasound assisted Lycium barbarum fruit extracts and pomegranate fruit peels. $J$. Food Meas. Charact. 2019, 13, 2017-2031. [CrossRef]

154. Llorent-Martínez, E.J.; Fernández-de Córdova, M.L.; Ortega-Barrales, P.; Ruiz-Medina, A. Characterization and comparison of the chemical composition of exotic superfoods. Microchem. J. 2013, 110, 444-451. [CrossRef]

155. Feng, L.; Tang, N.; Liu, R.; Nie, R.; Guo, Y.; Liu, R.; Chang, M. Effects of different processing methods on bioactive substances and antioxidation properties of Lycium barbarum (goji berry) from China. Food Biosci. 2021, 42, 101048. [CrossRef]

156. Liu, Y.; Cheng, H.; Liu, H.; Ma, R.; Ma, J.; Fang, H. Fermentation by multiple bacterial strains improves the production of bioactive compounds and antioxidant activity of goji juice. Molecules 2019, 24, 3519. [CrossRef] [PubMed]

157. Liu, Y.; Fang, H.; Liu, H.; Cheng, H.; Pan, L.; Hu, M.; Li, X. Goji berry juice fermented by probiotics attenuates dextran sodium sulfate-induced ulcerative colitis in mice. J. Funct. Foods 2021, 83, 104491. [CrossRef]

158. Liu, Y.; Gu, P.; Laaksonen, O.; Wei, B.; Zhu, Y.; Zhang, B.; Zhi, B.; Li, H. Lactic acid bacteria incubation and aging drives flavor enhancement of goji berry juice. J. Food Compost. Anal. 2022, 105, 104202. [CrossRef]

159. Niu, M.; Huang, J.; Jin, Y.; Wu, C.; Zhou, R. Volatiles and antioxidant activity of fermented Goji (Lycium chinese) wine: Effect of different oak matrix (barrel, shavings and chips). Int. J. Food Prop. 2017, 20, 1-13. [CrossRef]

160. Xia, Q.; Niu, M.; Wu, C.; Zhou, R. Formation of ethyl carbamate in goji wines: Effect of goji fruit composition. Food Sci. Biotechnol. 2016, 25, 921-927. [CrossRef]

161. Abuduaibifu, A.; Tamer, C.E. Evaluation of physicochemical and bioaccessibility properties of goji berry kombucha. J. Food Process Preserv. 2019, 43, e14077. [CrossRef]

162. Ducruet, J.; Rébénaque, P.; Diserens, S.; Kosińska-Cagnazzo, A.; Héritier, I.; Andlauer, W. Amber ale beer enriched with goji berries-The effect on bioactive compound content and sensorial properties. Food Chem. 2017, 226, 109-118. [CrossRef] 
163. Tang, P.; Giusti, M. Black goji as a potential source of natural colour in a wide pH range. Food Chem. 2018, 269, 419-426. [CrossRef]

164. Alsaggaf, M.S.; Moussa, S.H.; Elguindy, N.M.; Tayel, A.A. Fungal chitosan and Lycium barbarum extract as anti-listeria and quality preservatives in minced catfish. Int. J. Biol. Macromol. 2017, 104, 854-861. [CrossRef]

165. Kaldarbekova, M.; Uzakov, Y.; Chernukha, I.; Kurmanbekova, A.; Jetpisbayeva, B. Dtudying the effect of multicomponent pickle on the quality of cooked and smoked horse meat product. Period. Tche. Quim. 2019, 16, 259-265.

166. Uzakov, Y.; Kaldarbekova, M.; Kuznetsova, O. Improved technology for new-generationKazak h national meat products. Foods Raw Mater. 2020, 8, 76-83. [CrossRef]

167. Bulambaeva, A.A.; Vlahova-Vangelova, D.; Dragoev, S.; Balev, D.; Uzakov, Y.M. Development of new functional cooked sausages by addition of goji berry and pumpkin powder. Am. J. Food Technol. 2014, 9, 180-189. [CrossRef]

168. Fadıloglu, E.; Çoban, M. The effects of goji berry (Lycium barbarum L.) extract on some chemical, microbiological and sensory characteristics of liquid smoked common carp (Cyprinus carpio L., 1758) sausages. Yuz. Yil Univ. J. Agric. Sci. 2019, 29, 702-710.

169. Antonini, E.; Torri, L.; Piochi, M.; Cabrino, G.; Meli, M.A.; De Bellis, R. Nutritional, antioxidant and sensory properties of functional beef burgers formulated with chia seeds and goji puree, before and after in vitro digestion. Meat Sci. 2020, $161,108021$. [CrossRef] [PubMed]

170. Castrica, M.; Menchetti, L.; Balzaretti, C.M.; Branciari, R.; Ranucci, D.; Cotozzolo, E.; Vigo, D.; Curone, G.; Brecchia, G.; Miraglia, D Impact of dietary supplementation with goji berries (Lycium barbarum) on microbiological quality, physico-chemical, and sensory characteristics of rabbit meat. Foods 2020, 9, 1480. [CrossRef]

171. Menchetti, L.; Brecchia, G.; Branciari, R.; Barbato, O.; Fioretti, B.; Codini, M.; Bellezza, E.; Trabalza-Marinucci, M.; Miraglia, D. The effect of Goji berries (Lycium barbarum) dietary supplementation on rabbit meat quality. Meat Sci. 2020, 161, 108018. [CrossRef]

172. Istrati, D.; Vizireanu, C.; Iordachescu, G.; Dima, F.; Garnai, M. Physico-chemical characteristics and antioxidant activity of goji fruits jam and jelly during storage. Ann. Univ. Dunarea Jos Galati Fascicle VI_Food Technol. 2013, 37, 100-110.

173. Kosińska-Cagnazzo, A.; Bocquel, D.; Marmillod, I.; Andlauer, W. Stability of goji bioactives during extrusion cooking process. Food Chem. 2017, 230, 250-256. [CrossRef]

174. Olech, M.; Kasprzak, K.; Wójtowicz, A.; Oniszczuk, T.; Nowak, R.; Waksmundzka-Hajnos, M.; Combrzyński, M.; Gancarz, M.; Kowalska, I.; Krajewska, A.; et al. Polyphenol composition and antioxidant potential of instant gruels enriched with Lycium barbarum L. fruit. Molecules 2020, 25, 4538. [CrossRef]

175. Bora, P.; Ragaee, S.; Abdel-Aal, E.S.M. Effect of incorporation of goji berry by-product on biochemical, physical and sensory properties of selected bakery products. LWT 2019, 112, 108225. [CrossRef]

176. Pop, A.; Muste, S.; Man, S.; Crina, M. Study on the valorification of Lycium barbarum fruit (goji) in pastry products. Bull. Univ. Agric. Sci. Vet. Med. 2013, 70, 93-98. [CrossRef]

177. Ziemichód, A.; Różyło, R. Effect of the addition of goji berries on the physical properties of gluten-free bread. Acta Agroph. 2018, 25, 117-127. [CrossRef]

178. Morais Ferreira, J.M.; Azevedo, B.M.; Luccas, V.; Bolini, H.M. Sensory profile and consumer acceptability of prebiotic white chocolate with sucrose substitutes and the addition of goji berry (Lycium barbarum). J. Food Sci. 2017, 82, 818-824. [CrossRef]

179. Maurya, V.; Aggarwal, M. Impact of aqueous/ethanolic goji berry (Lycium barbarum) fruit extract supplementation on vitamin D stability in yoghurt. Int. J. Curr. Microbiol. Appl. Sci. 2017, 6, 2016-2029. [CrossRef]

180. Rotar, A.; Vodnar, D.; Bunghez, F.; Catunescu, G.; Pop, C.; Jimborean, M.; Semeniuc, C. Effect of goji berries and honey on lactic acid bacteria viability and shelf life stability of yoghurt. Not. Bot. Horti Agrobot. Cluj Napoca 2015, 43, 196-203. [CrossRef]

181. Taneva, I.; Zlatev, Z. Total phenolic content and antioxidant activity of yoghurt with goji berries (Lycium barbarum). Sci. Study Res. Chem. Chem. Eng. Biotechnol. Food Ind. 2020, 21, 125-131.

182. Shori, A.B.; Ling, Y.; Hj Baba, A.S. Effects of Lycium barbarum and fish collagen in cheese on the proteolytic degradation profile with anti-ACE activity. J. Food Process. Preserv. 2021, 45, e15239. [CrossRef] 